\title{
ЛЕКСИКОГРАФИЯ
}

https://doi.org/10.31912/pvrli-2020.3.11

\author{
Бьёрн Вимер \\ Университет Йоханнеса-Гутенберга \\ (Германия, Майни) \\ wiemerb@uni-mainz.de
}

\section{О СИНОНИМАХ И СУППЛЕТИВИЗМЕ НЕСКОЛЬКО ИНАЧЕ, ТО ЕСТЬ С ТОЧКИ ЗРЕНИЯ ОСНОВ}

В статье указывается, что проблемы, возникающие в связи с супплетивизмом, в известном смысле можно признать обратной стороной явлений, которые Ю. Д. Апресян рассматривал как проявления избыточности в парадигме глагольных основ, образующих так называемые видовые тройки. Как процессы, ведущие к супплетивизму, так и процессы, обусловливающие «переполнение» клеток в предполагаемых парадигмах, заставляют принимать решения о соотношении единиц словаря и грамматики. На этом фоне пересматривается классификация типов супплетивизма И. А. Мельчука и ряд положений, касающихся понятий лексемы и парадигмы. В результате обосновывается целесообразность ревизии представлений о морфологической парадигме и ее связи с понятием лексемы, которая учитывала бы глагольные основы как единицы, на которых строятся функциональные противопоставления, имеющие ключевую роль для грамматики русского языка. Вместе с тем выдвигается предложение учитывать в типологии супплетивизма не только степень регулярности формального соотношения объединяемых парадигматическими связями морфологических единиц, но и продуктивность морфологических образцов, причем как на уровне словарных единиц (включая варианты), так и на уровне текста (type vs. token frequency).

Ключевые слова: русский язык, парадигма, лексема, супплетивизм, видовые тройки, системная лексикография, глагольные основы, грамматические категории.

В настоящей статье я хочу показать, что хорошо известные идеи о роли структуры парадигм для системной лексикографии могут быть представлены в ином свете. Отправной точкой для этих рассуждений послужил ряд работ юбиляра, затрагивающих проблему «излишества» в парадигматических связях между единицами, морфологическим и лексикографическим отношениям которых обычно приписывался разный статус. Я стремлюсь к сопоставлению явлений, которые до сих пор в морфологических и лексикографических исследованиях скорее разъединялись 
(хотя бы частично), с тем, чтобы указать их сходство и чтобы высказаться за несколько измененный подход к «формату» единиц, соединяемых в парадигматических связях. Из соображений экономии места я ограничусь общей типологией затронутых здесь явлений и рядом частных вопросов.

\section{1. Исходные положения}

В «Лексической семантике» Ю. Д. Апресян [1995а: 173-175], рассматривая супплетивные отношения между разнокорневыми словами, обсуждал тройки слов типа:

(1а) бастовать - стачка / забастовка;

(1б) посещать - визит / посещение;

(1в) постановлять - резолюиия / постановление;

(1г) стоить - иена / стоимость.

В этих тройках выступают по два синонимичных (в определенной степени) существительных, из которых второе связано с глаголом словообразовательными аффиксами, а первое - нет. Поскольку в дополнительные отношения в качестве «именного репрезентанта» лексического концепта, выраженного глаголом, вступает уже второе, однокоренное существительное, то первое, разнокорневое существительное на право супплетивного отношения с глаголом претендовать не может. В этом смысле его в такой тройке можно считать лишним.

Такую «избыточность» Апресян сравнивал с ситуацией в несупплетивных тройках типа:

(2а) паковать - запаковать - запаковывать;

(2б) множить - умножить - умножать.

В отличие от троек в (1) все члены троек в (2) однокоренные и связаны словообразовательными аффиксами, все относятся к одной и той же части речи и у всех одно и то же лексическое значение. Однако в связи с принадлежностью к другому виду у среднего члена кардинально иное грамматическое распределение, чем у левого и правого членов, а эти два «крайних» члена между собой могут различаться всего лишь тонкими условиями употребления. В любом случае возникает вопрос, не нужно ли считать один из них лишним.

Тройки в (1) и в (2) роднит то, что между их членами наблюдается регулярное («нормальное») семантическое соотношение в рамках некоего лексического концепта; в этом смысле их члены могут считаться синонимами, но один из них может показаться излишним: в (1) это два члена, разделенные косой чертой, а в (2) это два крайних члена по отношению к среднему. Однако степень формального различия разная; разными также являются причины близкого семантического родства ${ }^{8}$.

${ }^{8}$ В отличие от троек типа (2) между членами троек типа (1) наблюдается не только различное этимологическое происхождение, но и намного больше разнообразия в семантических 
Поскольку и в формальном, и в семантическом плане члены троек типа (2) заметно ближе друг к другу, чем члены троек типа (1), то с их лексикографической трактовкой возникает больше проблем. Видимо, именно поэтому Ю. Д. Апресян [1995а: 174, сноска 4] подчеркивал, что иллюстрировать проблемы, связанные с супплетивизмом, удобнее как раз на примере троек типа (2). В более поздней работе [Апресян 1988], в основном воспроизведенной в [Апресян 1995б], юбиляр на примере этих троек разбирал вопрос синонимии и вариантов. Тройки типа (2) известны как видовые тройки, точнее как биимперфективные видовые тройки: «...на роль имперфективного коррелята претендует сразу два глагола» [Зализняк и др. 2015: 58 и след.]. По отношению к ним часто обсуждался вопрос, за каким из этих двух глаголов нужно признавать право быть «собственно видовым» коррелятом.

\section{2. Супплетивизм, синонимия и распределение по грамматическим функциям}

Прежде чем обратиться к этому вопросу, хотелось бы осветить теоретический фон, на котором Апресян провел нестандартную аналогию между тройками типа (1) и видовыми тройками. Исходной точкой для этой аналогии послужили положения Мельчука о супплетивизме 9 . Они эксплицитно учитывают продуктивные образцы в словообразовании и даже за его пределами [см.: Мельчук 2001: 420441]. Так, например, в [Mel'čuk 1994: 363; Мельчук 2001: 438 и след.] супплетивизм усматривается даже между полной фраземой и семантически соответствующим именем деятеля:

$$
\begin{aligned}
& \text { говорить красиво - краснобай; } \\
& \text { молоть языком - пустозвон. }
\end{aligned}
$$

Эти пары слов в целом могут быть охарактеризованы как антонимы друг к другу, а в формальном плане соотношения между членами каждой из пар одинаковые, хотя морфологически почти ничего общего между ними нет ${ }^{10}$. Столь далеко идущее применение понятия супплетивизма показывает, что различия между словоизменением и словообразованием (как бы они ни определялись) не имеют значения. Мельчуку в первую очередь важно охватить л юбы е образцы семантического соотношения между единицами языка, которые в какой-то заметной степени отклоняются от регулярных способов его формального выражения [cм.: Mel'čuk 1994:

отношениях. Апресян здесь приводит такие примеры, как действовать - эффект / действие, создавать - автор / создатель, а также примеры с другими частями речи, например единственный - только / единственно, совпадать - тождественный / совпадающий.

9 Хотя точной ссылки в данном месте книги не дается, понятно, что Апресян опирался на работу [Мельчук 1972]. Ее положения отразились и в более известной статье [Mel'čuk 1994].

10 Видимо, мысль о супплетивизме возникает именно из-за антонимии, позволяющей построить аналогичную схему:

$\begin{array}{ll}\text { говорить красиво } & : \text { молоть языком } \\ \text { краснобай } & : \text { пустозвон }\end{array}$


344; Veselinova 2006: 164]. При этом степень продуктивности выделяемых образцов, видимо, роли не играет ${ }^{11}$.

Что касается различия между словоизменительным и словообразовательным супплетивизмом, то считается, что в первом случае супплетивные знаки относятся к одной и той же лексеме (и поэтому здесь говорится о «формах»), а в случае второго - к разным лексемам, связанным отношениями производности [Мельчук 2001: 429].

Кроме этих особенностей, нужно отметить следующие положения Мельчука.

1. Понятие «супплетивизм» применяется к парам минимальных знаков, а таковыми считаются как морфы и мегаморфы (т.е. морфологически неразложимые сегменты, обслуживающие более одного грамматического и/или лексического значения) ${ }^{12}$, так и фразеологизованные словосочетания [Мельчук 2001: 421, 423], примеры которых можно увидеть в (3).

2. Супплетивизм - градуальное свойство, которое зависит от степени формальной нерегулярности [Мельчук 2001: 426-428, 439]. Самая сильная степень супплетивизма достигается, когда какие-либо два соотнесенных парадигматически знака $\mathrm{S}_{1}$ и $\mathrm{S}_{2}$ нельзя свести ни друг к другу, ни к какому-либо третьему знаку с помощью активных морфонологических чередований (например, реб-ён-ок-дет- $u$, но также четыре - сорок). Со слабым супплетивизмом мы имеем дело, когда обнаруживается какое-либо уникальное чередование, но «формальное сходство между $\mathrm{S}_{1}$ и $\mathrm{S}_{2}$ не слишком велико, чтобы признать их безоговорочно супплетивными» [Там же: 440]; ср. англ. child — child-ren, лит. žmog-us 'человек' — žmon-ёs 'люди', а также при-еха-ть - при-езжса-ть.

3. Как супплетивные могут определяться отношения не только среди лексических морф, т. е. аллолексов (например, франц. all-ons - i-r-ons '(мы) идем - пой-

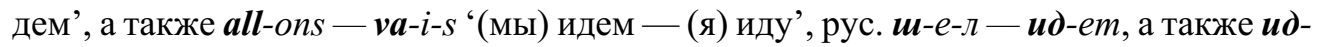
em (или $\boldsymbol{и д - m u ) ~ - ~} \boldsymbol{x} \boldsymbol{\partial}-\varnothing$, но и среди морф с грамматическими значениями (включая и словообразовательные), например (много) стол-ов, деревь-ев, словар-ей, книг-ө. Тем самым алломорфизм в области аффиксов трактуется как частный случай супплетивизма [Мельчук 2001: 422, 429, 433].

4. Мегаморфы могут выражаться в виде целых словоформ, представляющих сплав лексического значения с функциями граммем, т.е. корни неотделимы от грамматических показателей, а точнее говоря, корни сами выступают показателями грамматических значений в рамках определенных парадигм (ср. англ. am are - is - was - were - be).

5. Между тем исключается супплетивизм между лексическими синонимами, если между ними нет никаких грамматических различий (например, огромн-ыци громадн-biй). Хотя это явно не сказано, но причина очевидным образом состоит

11 Как раз с этой точки зрения примеры (3) очень сомнительны. В общем и целом проблемы с продуктивностью редко когда подвергались критической оценке в работах по супплетивизму: «The issue of productivity and generality of a derivational pattern is rarely discussed at length in relation to suppletion» [Veselinova 2006: 13]. Систематический обзор см. [Там же: 9-18, 163-169].

12 Более принятый термин - морфемы-портманто. 
а единая парадигма мыслима только по отношению к лексеме; понятия эти создают замкнутый круг. Если же следовать определению классифицирующей категории, данному в [Плунгян 2011: 53], то единства парадигмы по отношению к парным основам СВ и НСВ нет: «определенное множество лексем данного языка без остатка разбивается на непересекающиеся подклассы, каждый из которых характеризуется своим значением некоторой грамматической категории. Эта категория приписана, таким образом, лексемам, а не словоформам и задает грамматическую классификацию лексики» (курсив в оригинале).

В частном случае парные основы могут быть супплетивными, и то как исключения на фоне регулярных образцов, в соответствии с которыми глагольные основы связаны между собой деривационными аффиксами. А откуда тогда берутся значения граммем СВ : НСВ, которые приписываются этим основам? Очевидно, они выводятся только из глобального распределения морфологически соотносительных основ по разным группам функций. Грубо говоря, основы класса СВ выступают только в одних группах контекстов, основы класса НСВ встречаются, соответственно, в других, а контексты (функции) обоих классов в идеале распределены дополнительно. Отсюда и грамматический характер оппозиции СВ : НCB, и непересекающиеся подклассы (см. выше цитату из Плунгяна). Чтобы завершить круг рассуждений, нужно осознать, что разнокорневые, но синонимичные основы объединяются в видовые пары потому, что между ними наблюдается в принципе то же распределение, что и между членами видовых пар, образованных по регулярным аффиксальным образцам. Нужным может оказаться еще дополнительное условие, что такие разнокорневые основы не имеют регулярных соответствий противоположного вида. Почему без этого условия лексикографическая трактовка материала усложняется, станет понятным в $\$ 3.4$.

Далее, нужно понимать, что видовые пары - это всего лишь случаи полной лексической синонимии между основами с разным распределением по выше упомянутым контекстам, т.е. между представителями противопоставленных грамматических классов. Разное распределение между понимаемыми так синонимами включает устойчивые условия замены одного члена пары другим. Наиболее распространенные условия замены получили название частновидовые функиии. К ним относятся и те, в которых глагол НСВ мыслится как «заместитель» СВ в событийном значении (нарративное настоящее, многократное, а отчасти и общефактическое); эти условия получили название тривиальныле ${ }^{15}$. Разумеется, все эти условия и распределение по контекстам применяются по отношению к лексемам, представителями которых выступают основы. Но большая (если не преобладающая) часть споров о том, какие основы СВ и НСВ считать видовыми парами, вытекала из разных представлений о лексической синонимии и о тождестве лексических концептов. При этом нужно осознавать, что даже в бесспорных видовых парах толкования члена СВ и члена НСВ часто расходятся. Это показано, например, в работе [Гловинская 1982].

15 Более систематическое представление дается в [Зализняк, Шмелев 2000; Вимер 2001; 2017]. 


\section{3. Избыточность... чего? - вариантов, синонимов или функций?}

В дальнейшем я хочу обсудить, что в русской видовой системе делает супплетивные синонимы возможными. Заодно хочется указать на ряд проблем, которые возникают вследствие жесткой взаимной «увязки» понятий парадигмы и лексемы.

\section{1. Вариативные суффиксы}

Для обсуждения этих вопросов полезно вернуться к лексикографической трактовке видовых троек, изложенной в двух статьях нашего юбиляра [Апресян 1988; 1995б]. В них обсуждались не только биимперфективные тройки, но также тройки, в которых две основы НCB отличаются суффиксами $\{$ 'a $\} /\{\text { va }\}^{16}$ и $\{$ iva $\}$; например:

\begin{tabular}{lll} 
СВ & \multicolumn{1}{|l}{ НСВ } & НСВ \\
завернуть - заворачивать & завертьвать (покупку в бумагу) \\
заготовить - заготавливать / заготовлять (дрова на зиму) \\
осмыслить - осмыслять $/$ осмысливать (увиденное) \\
рассеять - рассеивать $/$ рассевать (пепел по ветру) \\
наре́зать - нареза́ть
\end{tabular}

Эти суффиксы вряд ли имеют статус отдельных морфем и даже статус алломорфов, поскольку сложно понять, на чем основывается их распределение. Сосуществующие основы НСВ практически не отличаются друг от друга значением, так что их следует считать вариантами, а вопрос о разных лексемах не встает. Именно этим данный тип троек кардинально отличается от биимперфективных троек (см. § 3.2). В тройках типа (5) основным вариантом НСВ обычно считается первый (перед косой чертой), а второй ущербен в том смысле, что он употребляется реже и часто ощущается как архаичный. Поскольку не удается установить общие правила распределения вариантов, каждый случай нуждается в индивидуальном словарном описании. В этом смысле он неудобен как для лексикографического описания, так и для установления связей с грамматическими правилами.

Как варианты Апресян оценивает также сосуществующие основы на -стичь и -стигнуть. Стоит отметить, что эти основы связанные, т. е. они не встречаются без приставок ${ }^{17}$. На самом деле такие варианты создают тройки, прямо противоположные тройкам в (5), поскольку две вариантные основы СВ противостоят одной основе НСB, например:

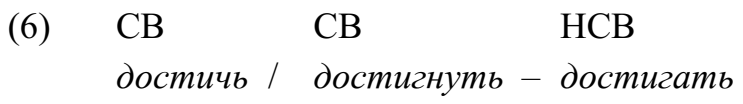

16 Для данного рассуждения не имеет значения, нужно ли считать $\{$ 'a $\}$ и $\{\mathrm{va}\}$ разными алломорфами или нет.

${ }^{17} \mathrm{Cp}$. с -нять (по-нять, при-нять, за-нять и т. д.) и рядом других случаев. О связанных корнях и основах см. [Плунгян 2000: 50-51]. 
Однако вариантные основы СВ обнаруживают тенденцию к дополнительному распределению финитных и нефинитных форм: от основ -стичь преимущественно образуются формы прошедшего времени, тогда как от основ - стигнуть - формы будущего времени и все нефинитные формы ${ }^{18}$ [Апресян 1988: 37], т. е. вариативные основы начинают «делить между собой» совокупность флективных форм, включая и те, которые входят в расширенную парадигму нефинитных форм.

По мере того как распределение приближается к дополнительному, о простой вариативности говорить не приходится. Поэтому в плане взаимодействия с грамматическими правилами тройки типа (6) нуждаются в более пристальном внимании, чем тройки типа (5), у которых тенденции к дополнительному распределению флективных финитных и нефинитных форм не наблюдается (по крайней мере, мне неизвестно, чтобы кто-либо такую тенденцию отмечал). Тем не менее тройки в (5) и (6) роднит то, что вариативность основ не влечет за собой семантических последствий, в частности нет сколько-нибудь заметной тенденции к дополнительному распределению по видовым функциям.

То же самое в принципе можно сказать и о другом типе, который Апресян обсуждал в связи с вариативностью суффиксов. Речь идет о случаях, когда основа без дополнительного суффикса ведет себя как двувидовая, но имеется и дериват с суффиксом \{iva $\}$, который принимает на себя функции $\mathrm{HCB}$; ср., например, apecтовать - арестовывать. Апресян трактует двувидовую основу как представителя двух ф о р м глагола: одной для СВ и одной для НСВ. О проблемах со словоизменительной трактовкой видовой оппозиции СВ : НСВ уже говорилось выше. Альтернативно на данные случаи можно смотреть и так: имеются основы, которые на фоне всей классифицирующей системы не ведут себя однозначно ни как НСВ, ни как СВ, но есть и дериваты, которые нужно расценить как основы НСВ, хотя они и недостаточно «надежны» (т.е. предсказуемы - в зависимости от контекстов, требующих или предпочитающих либо СВ, либо НСВ), и поэтому основа без этого суффикса может по-прежнему выполнять функции, «предусмотренные» для $\mathrm{HCB}^{19}$. Такая ненадежность и приводит к тому, что информация о возможности использования несуффигированной основы как НСВ заносится в индивидуальную словарную статью. В плане распределения видовых функций между такими основами получается асимметрия.

\section{2. Биимперфективные тройки}

В обсуждении биимперфективных троек полезно различать две вещи: принципиальные рассуждения относительно их лексикографической трактовки, с одной стороны, и критерии их подразделения, с другой. Мы начнем с первого вопроса;

18 В соответствии с [Veselinova 2006] такое распределение характерно для некатегориального супплетивизма (non-categorial suppletion).

19 Вместе с тем, как указывал Апресян, многие основы без суффикса \{iva\} ущербны в плане частновидовых функций, а их суффиксальные дериваты склонны использоваться в дополнительных частновидовых функциях [Апресян 1988: 36]. По сути это обратная сторона того же явления. 
для него окажется существенным понимание парадигмы и ее соотношения с понятием лексемы, т.е. той единицы, которая по сути является основным объектом лексикографического описания. В тройках бесприставочную основу НСВ я в дальнейшем буду называть $\mathrm{HCB}_{1}$, а основу вторичного имперфектива (с другим суффиксом) - $\mathrm{HCB}_{2}$. Ср., например:

$$
\begin{aligned}
& \mathrm{HCB}_{1} \mathrm{CB} \\
& \text { множить }- \text { умножить }- \text { умножать } \\
& \text { мести }- \text { подмести }- \text { подметать }
\end{aligned}
$$

Ю. Д. Апресян [1988; 1995б] рассматривает три альтернативные трактовки; первые две из них на деле реализованы в русской лексикографической практике. В соответствии с первой трактовкой в пару объединяются СВ и $\mathrm{HCB}_{2}$ :

$\begin{array}{ccc}\mathrm{HCB}_{1} & \mathrm{CB} \quad \mathrm{HCB}_{2} \\ \text { IPFV tantum }^{20} & \text { пара }\end{array}$

$\mathrm{C}$ ней проблема в основном такова, что семантически $\mathrm{HCB}_{1}$ отстоит от $\mathrm{CB}$ не больше, чем $\mathrm{HCB}_{2}$ от СВ. Предположение о том, что нет, например, * ${ }^{2}$ дельввать, * написывать (и что поэтому $\mathrm{HCB}_{1}$ делать и писать объединяются с СВ сделать и написать в пары), а существует $\mathrm{HCB}_{2}$ умножать и т.д., само по себе не дает основания усматривать разницу лексического значения между $\mathrm{HCB}_{1}$ и $\mathrm{HCB}_{2}$ [Апресян 1988: 39 и след.]. Вместе с тем представленное выше решение нельзя распространить на все тройки; ср., например, есть - съесть - съедать: тут скорее $\mathrm{HCB}_{2}$ отстоит от двух остальных основ (см. ниже).

Второй подход состоит в выделении двух равноправных пар таким образом, что СВ оказывается «шарниром», выступая членом СВ сразу в двух разных парах:

$$
\begin{array}{lll}
\mathrm{HCB}_{1} \mathrm{CB} & \mathrm{HCB}_{2} \\
\hline
\end{array}
$$

При таком решении проблема заключается в том, что «умножить объявляется формой СВ от двух разных слов, т. е элементов двух разных парадигм. Такое пересечение парадигм лингвистическая теория считает невозможным. <..> Получается парадокс: множить и умножать суть разные лексемы (синонимы), входящие в грамматическую парадигму одной и той же лексемы умножить» [Апресян 1988: 38]. Существенно, что данный парадокс возникает, оттого что между лексемой и парадигмой устанавливается одно-однозначная связь; поэтому нельзя «перекрестить» две парадигмы или, что при словоизменительном подходе равнозначно, две лексемы.

Желая избежать такого парадокса, мы могли бы обсудить еще и третье решение. Оно сводилось бы к тому, чтобы объединить все три члена тройки в единую парадигму:

$$
\begin{array}{lll}
\mathrm{HCB}_{1} & \mathrm{CB} & \mathrm{HCB}_{2} \\
\hline
\end{array}
$$

20 То есть основа НСВ без соотносительной основы СВ. 
Тогда $\mathrm{HCB}_{1}$ и $\mathrm{HCB}_{2}$ объявлялись бы вариантами друг друга, т. е., по сути дела, за ними признавался бы такой же статус, как за основами с вариативными суффиксами (типа засеивать / засевать; см. 5), хотя формальное различие между $\mathrm{HCB}_{1}$ и $\mathrm{HCB}_{2}$ больше, чем между такими суффиксальными вариантами.

Такую трактовку Апресян принципиально отвергает: «признание множить умножить - умножать формами одного слова и, следовательно, элементами одной парадигмы логически приводит к такой ревизии глагольных парадигм, которая ни в какую реалистическую картину языка не укладывается» [Апресян 1988: 39]. Такой подход нужно считать «противоестественным», поскольку мы признавали бы, что «язык позволяет себе роскошь иметь от двух до пяти одинаково жизнеспособных вариантов одной и той же грамматической формы, порождаемых к тому же вполне живыми, а иногда и продуктивными процессами видо- и словообразования» [Там же: 40]. Дело бы не кончилось одними тройками, а распространялось бы дальше - на четвертки, пятерки и т. д., например:

$$
\begin{aligned}
& \text { менять (иголки на шкуры - обменять -обменивать - поменять; } \\
& \text { платить (за проезд) - уплатить - уплачивать - заплатить; } \\
& \text { рвать (отночения) - разорвать - разрывать - порвать; }
\end{aligned}
$$

готовить (инструмент) - приготовить - приготавливать - приготовлять;

мерить (туфли) - примерить - примерять - примеривать;

кутать (ребенка в платок) - закутать - закутьльть - укутать - укутьватын;

лечить (ребенка от кори) - вылечить - вылечивать - излечить - излечивать;

молотить (рожь) - обмолотить - обмолачивать - смолотить - смолачивать;

копить (деньги) - накопить - накапливать - накоплять - скопить скапливать - (разг.) скоплять

В связи с этими принципиальными возражениями Апресян пишет, что разная номенклатура (словоизменение, словообразование, классификационная категория, видообразование) вряд ли поможет понять «сущность русского вида». С тем, что терминология, если она сводится лишь к замене ярлыков, сама по себе ничего не решает, нельзя не согласиться. Однако интересно, что Апресян сам часто говорит о «видообразовании», очевидно потому, что этот термин более «безопасен», чем традиционное деление на словоизменение и словообразование: этот термин не заставляет определять морфологический статус обсуждаемых операций и единиц по отношению к грамматике и словарю ${ }^{21}$. Все равно мы оказались в тупике: ни одна из рассмотренных трактовок

${ }^{21}$ Не желая вступать здесь в эту дискуссию, я хотел бы лишь указать на довольно длительную историю этого понятия, применяемого как своего рода «стратегия избежания». Эта история начинается по меньшей мере с работы [Исаченко 2003 (1960): 137] и продолжается поныне; ср. недавнюю статью [Горбова 2015]. 
не оказалась безупречной. Тем важнее предложение Апресяна, как выбраться из этого тупика: не следует впадать в иллюзию, будто возможно дать всем биимперфективным тройкам одинаковую трактовку; сходство их формального устройства необязательно говорит о том, что они тождественны также и содержательно.

Тем самым мы переходим к подразделению биимперфективных троек. Апресян [1988; 1995б] выделял четыре подтипа, причем представляют они собой лишь наиболее яркие участки некоторого континуума. Полужирным шрифтом обозначаются члены, которые, по Апресяну, имеют наибольшие права на парность:

$\mathbf{H C B}_{1}-\mathbf{C B}-\mathrm{HCB}_{2}$ например: вить (гнездо) - свить - свивать

$\mathrm{HCB}_{1}-\mathbf{C B}-\mathbf{H C B}_{2}$ например: жать (штангу) - выжать - выжимать

$\left(\mathrm{HCB}_{1}\right)-\mathbf{C B}-\mathbf{H C B}_{2}$ например: гореть - сгореть - сгорать

$\mathbf{H C B}_{1}-\mathbf{C B}-\left(\mathrm{HCB}_{2}\right)$ например: nuть - выпить - выпивать

Интерес вызывает прежде всего второй подтип. В нем право на видовую парность признается за СB и $\mathrm{HCB}_{2}$, а $\mathrm{HCB}_{1}$ считается IPFV tantum, синонимичным с парой $\mathrm{CB}-\mathrm{HCB}_{2}$. Однако $\mathrm{HCB}_{1}$ употребляется взамен форм этой пары в речи, если у говорящего «возникает в этом необходимость, например: Tbl что сейчас делаешь? - Пакую вещи. - Когда запакуешь, зайди» [Апресян 1995а: 175; 1988: 42; 1995б: 111]. См. также:

$$
\text { — Что ты делаешь? - Мету пол. — Когда подметешь, вымой посуду. }
$$

В таких случаях говорится о «несобственных формах» и указывается на параллель со словообразовательным супплетивизмом из (1): - Сколько стоит эта книга? - Пять. - За такую цену ее никто не купит, хотя тут о (несобственных) формах той же лексемы нет речи.

В этом механизме Апресян усматривает компенсацию «дефектной парадигмы одной лексемы за счет форм другой, синонимичной ей лексемы» [Апресян 1988: 42], и здесь он вводит разграничение между системой (фиксируемой в словаре) и узусом (наблюдаемым в речи). Тут напрашивается вопрос, почему вообще парадигма видовой пары считается дефектной; иначе говоря, почему в примерах типа (12) не употребляется $\mathrm{HCB}_{2}$ подметаю? Если подметать и мести синонимичны, но только подметать определяется в качестве «парного» НСВ к СВ подмести, то естественно ожидать, что подметать может выбираться во всех основных видовых функциях, свойственных основам НСВ, в том же лексическом значении, что и $\mathrm{CB}$, или что подметать имеет хотя бы больше видовых функций, чем мести, в разных типах контекстов, в которых СВ заменяется на равнозначный $\mathrm{HCB}$. А если $\mathrm{HCB}_{1}$ и $\mathrm{HCB}_{2}$ возможны в равной мере, то весь вопрос сводится к тому, какой из них чаще на деле реализуется в каком-то достаточно четко определенном типе контекстов (т. е. в том или ином частновидовом значении). А то, что окажется более частотной реализацией, будет соответствовать системе или узусу?

Подобное явление, как и подобный вопрос, возникает применительно к $\mathrm{HCB}_{1}$ из третьего подтипа, ср.: 
- Спасибо скажи, что не пишу протокол, не привлекаю. - Не дам... Я лучше сожгу его! - Жги ... - спокойно ответил участковый и поднял глаза, огляделся. - Жги. Как раз ветерок к твоей хате. Ветер и вправду с утра шумел, серебря маковки тополей, легко пригибая их (Б. Екимов. Пиночет. 1999) [НКРЯ].

В третьем подтипе $\mathrm{HCB}_{1}$ считается более отдаленным от $\mathrm{CB}-\mathrm{HCB}_{2}$, потому что приставочные основы не могут употребляться в контекстах, в которых предел подавляется (или он нерелевантен); ср.: В комнате горит / *сгорает лампа или Костер горит $\neq$ сгорает быстро. Напротив, в четвертом подтипе $\mathrm{HCB}_{2}$ считается более отдаленным от $\mathrm{HCB}_{1}-\mathrm{CB}$, поскольку $\mathrm{HCB}_{2}$ употребителен в многократных контекстах, но неприменим или избегается в процессной функции (ср. Смотри, он nьет / *выпивает) $)^{22}$. Здесь стоит обратить внимание, что обоснования для определения «собственно видовой пары» из двух НСВ в каждом из двух случаев разные: в четвертом подтипе обоснование опирается на ограниченный набор частновидовых функций у $\mathrm{HCB}_{2}$, тогда как в третьем подтипе обоснованию подлежат различия в семантическом потенциале и вместе с тем разные синтаксически реализуемые валентности.

На самом деле одни и те же исследователи, подразделяя типы биимперфективных троек, исходят из разных критериев. Их можно вкратце охарактеризовать следующим образом.

1. Какой НСВ заменяет СВ в тривиальных условиях? Здесь на первом плане стоит возможность онтологического тождества обозначаемой ситуации.

2. Имеют ли $\mathrm{HCB}_{1}$ и $\mathrm{HCB}_{2}$ тенденцию к дополнительному распределению по частновидовым функциям (включая тривиальные), т.е. различаются ли оба $\mathrm{HCB}$ в семантическом (акциональном) плане, но каждый из них может лексически заменить СВ? Если да, то следует ли это расценить как свидетельство того, что оба HCB образуют с СB совместную парадигму (как в формальном, так и в функциональном отношении)? Апресян от такой возможности категорически отказался, назвав ее «противоестественной» (см. выше).

3. Какой из НСВ обладает более широким набором частновидовых (в том числе тривиальных) функций и выступает в них чаще, чем другой НСВ? И какие из этих значений следует признать основными? В принципе такой вопрос был задан в [Апресян 1997], но трудно сказать, какие значения следует признать (более) основными.

4. У какого из НСВ больше совместных с СВ лексических значений (включая их варианты) с учетом синтаксически реализуемых валентностей? Этот вопрос четче всех ориентирован на лексикографическое описание. См. соответствующий анализ в [Храковский 2005: 53-57], а также анализ «биперфективной» тройки в [Богуславская 2012] (см. § 3.3).

Эти критерии практически нигде эксплицитно не различаются, хотя во многих случаях они приводят к разным результатам, прежде всего в оценке троек [см.: Вимер 2019: 49-56].

22 Точнее говоря, процессная функция возможна, но только если дополнительно вводятся количественные ограничители действия; ср.: Смотри, он выпивает одну кружку за другой. 
Как бы то ни было, способность $\mathrm{HCB}_{1}$ заменять $\mathrm{CB}$, особенно в тройках подтипов 3 и 4, Ю. Д. Апресян [1995б] охарактеризовал как функцию «джокера»: $\mathrm{HCB}_{1}$ способен обозначать тот же лексический концепт, что и СВ (и парный с ним $\mathrm{HCB}_{2}$ ), только менее точно; уточнение же вносит речевой контекст. И тут снова возникает вопрос о том, что в каком-то определенном типе контекстов реализуется чаще. Конечно, на этот вопрос можно ответить только после корпусного исследования, в котором тщательно контролируются контекстные условия. Но даже если такое весьма трудоемкое - исследование будет проведено и окажется, что в тройках, относящихся к любому из указанных выше подтипов (по Апресяну), $\mathrm{HCB}_{1}$ заменяет $\mathrm{CB}$ чаще, чем $\mathrm{HCB}_{2}$, то какой вывод можно будет из такого результата извлечь для словарного описания? Нельзя отрицать существование $\mathrm{HCB}_{2}$, но $\mathrm{HCB}_{1}$ может оказаться более предсказуемым в качестве «лексической копии» СВ в тех контекстах, в которых СВ употребляться не может (или избегается).

Оппозиция между системой и узусом становится шаткой (или вообще распадается), если то, что считают «потенциалом системы», лишь изредка реализуется в речи (или не реализуется вообще). Апресян сам, хотя и косвенно, приходит к подобному выводу в двух моментах. Первый момент просматривается в критериях выделения четвертого подтипа биимперфективных троек, в которых $\mathrm{HCB}_{2}$ признается искусственным. Такие $\mathrm{HCB}_{2}$ «могут быть получены по продуктивным моделям видообразования, но скорее в виде потенциальных, чем реально используемых форм» [Апресян 1988: 41]. Второй момент был уже отмечен выше в связи с первой из возможных лексикографических трактовок биимперфективных троек: нельзя сказать, что объединение $\mathrm{HCB}_{2}$ (например, умножать) и $\mathrm{CB}$ (умножить и т. д.) в видовую пару само по себе может быть достаточным основанием для того, чтобы признать соотносительный $\mathrm{HCB}_{1}$ (множить и т. д.) IPFV tantum, и наоборот - что самим отсутствием $\mathrm{HCB}_{2}$ (например, сдельввать, написывать) можно обосновать решение, чтобы признать бесприставочную основу НСВ и соотносительную основу СВ видовой парой (делать - сделать, писать - написать и т.д.). В обоих лексикографических рассуждениях за исходное берется реализуемое, а не потенциальное. Вместе с тем вряд ли случайно, что искусственное отождествляется с редким, т. е. частотность хотя бы на интуитивном уровне влияет на предварительную сортировку материала по лексикографическим типам.

Вернемся еще ко второму из упомянутых только что рассуждений: ошибкой было бы считать бесприставочную основу глаголом IPFV tantum по одной лишь причине, что имеется $\mathrm{HCB}_{2}$ от соотносительной основы $\mathrm{CB}^{23}$. Для лексикографии проблемы создает особенно то обстоятельство, что вторичные имперфективы стали самым продуктивным способом образования основ НСВ из основ СВ. Существует много окказиональных и прочих образований, не принятых современной лексикографией, но иногда проживающих «подпольно» очень долгое время. Например,

${ }^{23}$ Обратной стороной той же медали является мнение разных ученых, что $\mathrm{HCB}_{2}$ следует считать излишним, если имеется однокоренной $\mathrm{HCB}_{1}$ (= бесприставочная основа). См., например, мнение П. С. Кузнецова в [Виноградов 1952: 320]. 
написывать в [НКРЯ] (старая версия, запрос делался в середине июля 2019 г.) имеет всего лишь девять вхождений в восьми документах, а последнее вхождение приходится на 1920 г.:

(14) Я в беспрерывном творчестве. Но вовсе не ведаю, что мне делать с написывающцмися стихами (К. Д. Бальмонт. Письма М. А. Волошину. 1920).

Между тем запрос в «Гугл» (середина июля 2019 г.) позволил убедиться, что основа $\mathrm{HCB}_{2}$ написывать (во всех основных употреблениях $\mathrm{HCB}_{1}$ писать) попрежнему «жива». Нетрудно найти примеры типа:

(15) Почему девушки часто начинают написывать бывшим парням в соцсети после того, как случайно их встретят на улице?? [https:/otvet.mail.ru/ question/215265044].

Ввиду таких фактов постоянно возникает проблема учета «избыточности» с точки зрения лексикографии. На их примере можно убедиться в том, что язык (так сказать, через речь) постоянно позволяет себе роскошь излишества, причем несущественно, какой морфологический (и грамматический) статус мы будем признавать за наблюдаемой избыточностью (словоизменение, словообразование или, во избежание лишних дискуссий, видообразование). Намного интереснее понять, какие факторы приводят к тому, что одни варианты пробивают себе путь, другие вытесняются, а третьи могут сосуществовать довольно долго. И интересно, примет ли системная лексикография вызов, чтобы отражать эту динамику в своем моделировании.

«Редундантные отношения», стоящие за появлением вторичных имперфективов и за устройством той части видовой системы, которая связана с тройками (в частности, с биимперфективными), часты. Они могут появиться и снова исчезнуть в отдельных случаях, но как общее, динамическое явление они, видимо, будут сохраняться, пока вторичная имперфективация не перестанет быть продуктивной, а бесприставочные основы не исчезнут, - а ни на то, ни на другое не похоже.

Замечательно, что подобная динамика учитывалась в двух случаях супплетивизма, из которых один прямым образом связан с видом (§ 3.3), а другой показывает рост тенденции к дополнительному распределению этимологически различных, но синонимичных основ (§ 3.5). К этому можно добавить случаи наложения супплетивизма на видовые тройки, расположенные будто бы посередине (§ 3.4). Все эти явления хорошо вписываются в типологию соотношений супплетивизма и синонимии. Поэтому ими хочется завершить настоящий обзор.

\section{3. Особый случай: биперфективная видовая тройка}

В работе [Богуславская 2012] был проведен анализ корпусных данных, показывающих, как на протяжении примерно 250 лет в морфологически регулярной паре НСВ - СВ член СВ заменялся на другой, этимологически (почти) не соотносительный: в паре возвращзать - возвратить на смену возвратить все больше 
приходил вернуть; аналогичная ситуация имела место и относительно возвратного возвращаться - возвратиться / вернуться ${ }^{24}$. Замена не дошла до конца, поэтому и сегодня вернуть (ся) и возвратить (ся) сосуществуют рядом практически во всех своих значениях и на этом основании имеют почти одинаковое право на видовую парность с НСВ возвращать (ся).

Правда, вернуть (ся) сегодня намного частотнее, чем возвратить(ся). С одной стороны, более старый член СВ (возвратить(ся)) лучше укоренен в языковой системе в том смысле, что у него более развиты словообразовательные связи (ср. возврат, невозвратный и т.д.); от этой основы также образуется причастие в пассиве, тогда как вернуть не образует нужных для пассива форм причастий, т. е. его парадигма слегка дефектна. Заодно перед нами дополнительное распределение, подобное распределению у связанных основ типа -стичь/-стигнуть (см. § 3.1). С другой стороны, у вернуть и вернуться чуть более развита полисемия (с вариантами значений), чем у возвратить и возвратиться [см.: Богуславская 2012: 77-82]. В то же время необходимо учесть также приставочные дериваты обеих основ СВ. Для возвратить таких дериватов нет (может быть, потому, что в эту основу уже входит приставка), зато у вернуть их множество, ср. неполный список: ввернуть, вывернуть, повернуть, свернуть, завернуть, провернуть, развернуть, отвернуть, перевернуть, подвернуть (аналогично для вернуться vs. возвратиться).

Устройство тройки возвращаться - возвратиться / вернуться представляет собой зеркальное отражение устройства биимперфективных троек, и поэтому ее можно назвать биперфективной. Но на этом, пожалуй, сопоставимость кончается. Во-первых, биперфективная тройка строится на супплетивной замене (см. сноску 17); бывшая видовая пара возвращзаться - возвратиться в формальном отношении подверглась расподоблению. Во-вторых, насколько мне известно, такой случай для русского языка единичен, в то время как биимперфективных троек весьма много. Эта уникальность объясняется, видимо, тем, что верну- - одна из немногих бесприставочных основ (из славянского фонда морфем), которые относятся к $\mathrm{CB}$, а также тем, что вернуть(ся) с точки зрения морфемной структуры не обладает (с середины XVIII в. ${ }^{25}$ ) эквивалентом НСВ. Поэтому до того, как эти основы «вторглись» на место возвратить (ся), их можно было отнести к perfectiva tantum. Есть, правда, случаи (тоже единичные), в которых основа СВ с одной приставкой

24 Корни верт(еть) / вер(нуть) и ворот(ить) этимологически родственны в очень далеком прошлом [подробнее см.: Богуславская 2012: 76], но вряд ли распознаваемы как однокоренные в современном языке, а врат (umb) — церковнославянское соответствие полногласного ворот(umb). Оба тем самым изначально являются вариантами, но (как обычно в литературном русском языке при «дублетах» славянизма и его восточнославянского эквивалента) сейчас находятся в практически дополнительном лексическом распределении. К тому же -вратить превратилось в связанную основу.

25 Судя по данным [НКРЯ] и по словарю В.И. Даля [1: 182], вертеть и вертеться по крайней мере с середины XVIII в. выступали только в тех значениях, которые известны в современном языке. Однокоренные основы верте $(m b)$ и верну $(m b)$ должны были семантически разъединиться достаточно давно. 
«подшивается» под однокоренную пару с другой приставкой; ср. уснуть по отношению к заснуть - засыпnámb. Но в таком случае, как правило, о тройке не говорится. Видимо, это не столько потому, что уснуть стилистически маркировано и вместе с тем встречается несколько реже, чем заснуть (7 809 против 11206 вхождений в [НКРЯ] - новая версия, запрос от 22 ноября 2019 г.), сколько потому, что мену приставок не считают проявлением алломорфизма, даже если получаемые основы синонимичны (в отличие от мены суффиксов; см. § 3.1). Следовательно, однокоренные основы с разными приставками трактуются как разные лексемы.

\section{4. Обязательно ли супплетивизм противодействует лексическому единству в тройке?}

На этом фоне интересно отметить, что возникновение супплетивной пары $\mathrm{HCB}$ - СВ может помешать образованию биимперфективной тройки. См. соотношения основ в (16):

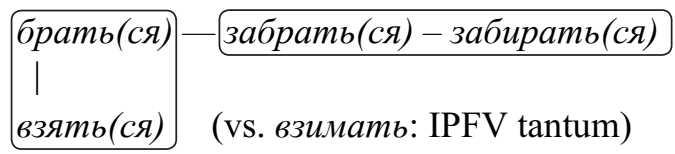

Когда-то основа СВ взять(ся) семантически отъединилась от «родственной» основы НСВ взимать(ся). Взимать обособилось как imperfectivum tantum, но взять (ся) вступило в дополнительное грамматическое распределение со своим синонимом брать(ся), так что обе основы стали одной из самых частотных, если не самой частотной видовой парой. Теперь на момент отвлечемся и прикинем, что случилось бы, если бы основы НСВ брать(ся) не «нашли себе» дополнительных партнеров СВ взять(ся). Тогда было бы трудно отказаться от мысли, что брать(ся) имеет смысл рассматривать как $\mathrm{HCB}_{1}$ к забрать (ся) - забирать (ся), а все три основы вместе - как биимперфективные тройки. По сути дела, и сегодняшний супплетивизм брать (ся) - взять(ся) в принципе не мешает рассматривать такую нестандартную трактовку: в (16) была бы представлена биимперфективная тройка с одним разнокорневым синонимом, дублирующим функции члена СВ. Насколько я могу судить, лексикографическая практика такую альтернативную трактовку не учитывает. И если это так, то такая практика имплицитно признает супплетивизм по виду более адекватным «отражением реальности», чем возможность объединения бесприставочных основ НСВ в тройки (или соединения супплетивизма с тройкой).

Что, однако, делать в случае, когда от бесприставочной основы НСВ образуется сразу два деривата СВ с разными приставками и каждый из этих дериватов, в свою очередь, образует вторичный имперфектив? При этом все пять основ имеют одинаковое лексическое значение. См., например:

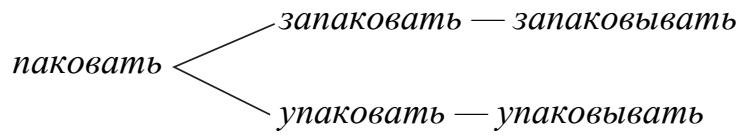


Такие случаи не обособленны, так что ими пренебречь нельзя (см. подробный разбор в [Janda et al. 2013: §§ 5-6]). Перед нами как будто две вставленные друг в друга биимперфективные тройки четвертого подтипа (см. § 3.2), а вдобавок оба приставочных СВ имеют равное право считаться «собственно видовым» коррелятом НСВ паковать. В [Апресян 1995а: 174-175] эта ситуация представляется как своего рода дилемма (с точки зрения словоизменения), поскольку не только паковать соотносится одновременно с двумя синонимичными дериватами $\mathrm{CB}$, но и все дериваты СВ и НСВ с приставками за- и $y$ - синонимичны друг другу и поэтому могут в пределах «своих» частновидовых значений заменять друг друга.

Думается, что дилемма снимается, если допустить полностью синонимичные отношения между однокорневыми видовыми парами с разными приставками, которые в дополнение ведут себя как «спаренные» через $\mathrm{HCB}_{1}$ биимперфективные тройки. Если $\mathrm{HCB}_{1}$ паковать все равно признается «джокером» (см. § 3.2), то оно с лексикографической точки зрения и так стоит особняком, а «группировки родственных основ», как в (17), предстают как крайние случаи, когда вследствие деривации основ в пределах одной части речи лексическое значение остается неизменным. В конце концов, тройкам как таковым в праве существования не отказывают (см. $\S 3.2$ ), а существуют также синонимичные видовые пары, образованные от разных корней, у которых распределение видовых функций (в большей или меньшей мере) совпадает, но никто не думает объединять их в одну парадигму; ср., например, близкозначные пары зарывать - зарыть и закапывать - закопать, спешить - поспешить и торопиться - поторопиться, притворяться - притвориться и прикидываться - прикинуться, отнимать - отнять и отбирать — отобрать.

Здесь можно вернуться к началу статьи и указать на аналогию между «пятеркой» в (17) и словообразовательной пятеркой с меной части речи и супплетивными членами, как в (18):

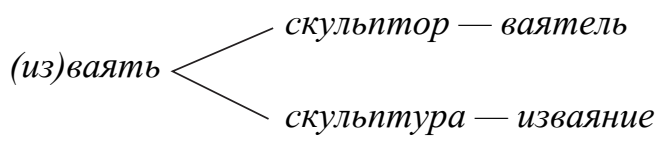

Исходный глагол становится «шарниром» для двух пар синонимов, в каждой из которых один член делит корень с исходным глаголом. Соотношение между ваять и скульптор / ваятель (или между изваять и скульптура / изваяние) вряд ли можно считать тройкой, но собственно только потому, что ни между синонимичными существительными (в каждой паре), ни между глаголом и любой из пар существительных нет грамматических условий распределения (кроме «тривиальных» условий, требующих той или иной части речи).

\section{5. Слияние неполных парадигм синонимов в единую супплетивную парадигму}

В работе [Апресян 2002: § 2.1] описывается процесс взаимного дополнения парадигмы финитных и нефинитных форм двух близкозначных глаголов - хотеть и желать: хотеть стилистически нейтрально употребляется в финитных формах 
утвердительных и вопросительных предложений, а желать - в нефинитных формах и в императиве, к тому же этот глагол обладает более развитыми словообразовательными связями (ср. желание, пожелание, желательный). Апресян подводит следующий итог: «Распределение личных и неличных форм глаголов хотеть и желать еще не приобрело той стройности, которая характеризует дополнительное распределение. В частности, у обоих есть нейтральный инфинитив» [Там же: 19]. Тем не менее: «Налицо тенденция к слиянию двух неполных парадигм близко синонимичных глаголов в одну супплетивную парадигму. <..> В результате желать и хотеть тяготеют к слиянию в один глагол с супплетивной грамматической и словообразовательной парадигмами, в которых все члены стилистически нейтральны» [Там же: 19].

Как этот пример, так и пример с вернуть(ся) в 3.3 уместно считать случаями превращения «несобственных форм», заполняющих лакуны в парадигме другой основы, в супплетивные эквиваленты ${ }^{26}$. Впрочем, даже среди членов достаточно бесспорных видовых пар синонимия может оказаться неполной. Так, например, А. Д. Шмелев [2012: 584] показал, что НСВ ударять не может заменять «свой» СВ ударить в сочетании ударить по воротам. В этом (и видимо, только в этом) сочетании место ударять занимает бить (по воротам). Такой идиосинкратический случай иллюстрирует зачаток развития фразем, включающих супплетивизм. Заодно такие зачатки создают лексикографические проблемы различения вариантов и синонимов.

Конечно, для каждого отдельного случая встает вопрос, действительно ли лакуны возникли до того, как их стали заполнять формы другой основы (pull-in effect), или же регулярные формы парадигмы вытеснялись вроде бы «излишними» формами синонимичной основы (push-out effect). Но сравнение таких случаев показывает, что подобные процессы приводят к изменениям в видовой парности так же, как и в более традиционных парадигматических отношениях (обсуждаемых в рамках словоизменения).

\section{4. Заключение}

Явления, в которых можно усмотреть супплетивизм, крайне интересны для оценки «серой зоны» между словарем и грамматикой [Veselinova 2006], и тем самым для фундаментальных задач системной лексикографии. Супплетивные отношения нельзя считать просто случайными причудами языка. Напротив, они свидетельствуют о том, что парадигматические структуры подвержены изменениям, и в большой мере из-за того, что между членами этих структур часто наблюдается асимметрия, а семантически или функционально близкие средства, у которых по разным причинам меняется продуктивность, способны занимать «слабые звенья» (или клетки) в парадигмах. Это верно независимо от того, какой

26 Этот механизм хорошо описан в [Veselinova 2006], причем как для категориального, так и для некатегориального супплетивизма. 
морфологический статус признается за задействованными единицами; как справедливо сказано в [Veselinova 2006: 10]: «...it is not always entirely clear where one is to draw the line between suppletive forms related in a derivational way on the one hand, and separate lexical items on the other. In this respect, suppletion draws the limit of the possible word». Как я попытался показать, в известном смысле обратной стороной супплетивизма являются рассмотренные Апресяном типы избыточности форм в парадигме. Процессы, ведущие к супплетивизму, равно как процессы, обусловливающие «переполнение» клеток в предполагаемых парадигмах, заставляют принимать решения о соотношении единиц словаря (а такая единица принимается как общее для всех форм парадигмы значение) и грамматики (в которой определяются правила соединения словарных единиц с членами парадигмы).

Заодно решения, которые принимаются в серых зонах, много говорят о модели, заложенной самими лингвистами. С особой остротой проблемы вырисовываются, когда мы углубляемся в исследование типов образования глагольных основ в русском языке. Поскольку вид относится к стержневым грамматическим категориям в любом славянском языке, а в дополнение он теснейшим образом связан с глагольной лексикой (не только в славянских языках), эти проблемы оказывались устойчивыми с момента возникновения аспектологических разысканий также и для русского языка и, естественно, для концепции интегрального словаря. Сомнительно, что эти проблемы удастся преодолеть, если вокруг видообразования ведутся споры о том, нужно ли рассматривать русский вид как словоизменительную категорию или как другой тип категории, а не спрашивается просто о том, какой ти п е дин иц создает парадигматические отношения - и на основании каких семанти ческих (или функциональных) противопоставлений. Вместе с тем необходимо определиться, сколь жестко понимается лексическое тождество и как поступать с зачатками идиосинкратического ограничения лексической сочетаемости (ср. пример бить / *ударять - ударить по воротам, приведенный в § 3.5), а также как расценивать различия в частотности вариантов или синонимов (см. § 3.13.2). В связи с супплетивизмом Мельчук задавал шкалу регулярности (по форме), но очевидным образом мы нуждаемся также в шкале по продуктивности применения морфологических образцов, причем отдельно для продуктивности в отношении словарных единиц (включая варианты) и в отношении реализации на уровне текста (type vs. token frequency). Уместно расширить учет супплетивизма на уровень соотношения основ, связанных словообразовательными отношениями в пределах одной части речи. Мельчук предпринял этот шаг фактически именно на примере супплетивных видовых пар, хотя тем самым он показал неправомерность одной из своих предпосылок (см. § 2). Супплетивные видовые пары строятся на синонимии глагольных основ с дополнительным распределением по грамматически релевантным контекстам. Вдобавок хотя бы одна из этих основ должна была «лишиться» своего коррелята оппозитивного вида; если же у другой основы осталась связь с синонимичной и словообразовательно «родственной» основой противоположного вида (или со стандартной видовой парой), возможные супплетивные и регулярные отношения накладываются друг на друга (ср. пример 16). 
Предложенное расширение типологии супплетивизма позволяет увидеть градуальность и сходство в соотношениях между корнями, основами и аффиксами, т.е. между единицами разного морфологического «формата» (и способами их соединения). В связи с этим стоило бы подумать над ревизией представлений о морфологической парадигме и ее связи с понятием лексемы. В частности, почему нельзя признать единую парадигму за родственными, но разными лексемами, например в видовых тройках?

\section{Литература}

Апресян Ю.Д. Морфологическая информация для толкового словаря // Словарные категории / отв. ред. Ю. Н. Караулов. М. : Наука, 1988. С. 31-53.

Апресян Ю.Д. Лексическая семантика: синонимические средства языка. М. : Языки русской культуры, 1995а. 481 с.

Апресян Ю. Д. Трактовка избыточных аспектуальных парадигм в толковом словаре // Апресян Ю. Д. Избр. тр. Т. 2 : Интегральное описание языка и системная лексикография. М. : Языки русской культуры, 1995б. С. 102-113.

Апресян Ю. Д. Лексикографическая трактовка вида: нетривиальные случаи // Труды аспектологического семинара Филологического факультета МГУ им. М. В. Ломоносова. Т. 2 / отв. ред. М. Ю. Черткова. М. : Изд-во МГУ, 1997. С. 7-20.

Апресян Ю. Д. Взаимодействие лексики и грамматики: лексикографический аспект // Русский язык в научном освещении. 2002. №3 (1). С. 10-29.

Богуславская О. Ю. Близкие синонимы: 250 лет соперничества // Смыслы, тексты и другие захватывающие сюжеты : сб. ст. в честь 80-летия И. А. Мельчука / отв. ред. Ю. Д. Апресян и др. М. : Языки славянских культур, 2012. С. 75-86.

Вимер Б. Аспектуальные парадигмы и лексическое значение русских и литовских глаголов (Опыт сопоставления с точки зрения лексикализации и грамматикализации) // Вопросы языкознания. 2001. № 2. С. 26-58.

Вимер Б. О роли приставок и суффиксов на ранних и поздних этапах истории славянского вида // The Role of Prefixes in the Formation of Aspectuality (Issues of Grammaticalization) / ed. by R. Benacchio, A. Muro, S. Slavkova. Firenze : Firenze University Press, 2017. P. 219-253.

Вимер Б. О семантически инвариантном и грамматически тривиальном в русском виде // Сборник статей к 85-летию В. С. Храковского / отв. ред. Д. С. Герасимов, С. Ю. Дмитренко, Н. М. Заика. М. : Языки славянских культур, 2019. С. 43-66.

Виноградов В. В. Современный русский язык. Морфология (Курс лекций). М. : Изд-во МГУ, 1952. 519 с.

Гловинская М.Я. Семантические типы видовых противопоставлений русского глагола. М. : Наука, 1982. 155 с.

Горбова Е. В. Видообразование русского глагола: префиксация и/или суффиксация? // Вопросы языкознания. 2015. №1. С. 7-38.

Даль В. И. Толковый словарь живого великорусского языка : в 4 т. М. : Гос. издво иностр. и нац. словарей, 1956. 
Зализняк А. А. Русское именное словоизменение. М. : Наука, 1967. 760 с.

Зализняк А. А., Микаэлян И.Л., Шмелев А. Д. Русская аспектология: в защиту видовой пары. М. : Языки славянских культур, 2015. 392 с.

Зализняк А. А., Шмелев А. Д. Введение в русскую аспектологию. М. : Языки славянских культур, 2000. 226 с.

Исаченко A.В. Грамматический строй русского языка в сопоставлении с словацким. Морфология. Ч. 2. М. : Языки славянских культур, 2003. 570 с.

Мельчук И. А. О супплетивизме // Проблемы структурной лингвистики - 1971 / отв. ред. С. К. Шаумян. М. : Наука, 1972. С. 396-438.

Мельчук И. А. Курс общей морфологии. Т. 4. Ч. 5 : Морфологические знаки. М. ; Вена : Языки славянских культур, 2001. 580 с.

НКРЯ - Национальный корпус русского языка [Электронный ресурс]. URL: http://ruscorpora.ru/

Плунгян B.A. Общая морфология (Введение в проблематику). M. : URSS, 2000. $384 \mathrm{c}$.

Плунгян В.A. Введение в грамматическую семантику: грамматические значения и грамматические системы языков мира. М. : Изд-во РГГУ, 2011. 672 с.

Храковский В. С. Аспектуальные тройки и видовые пары // Русский язык в научном освещении. 2005. № 1. С. 46-59.

Шмелев А. Д. Супплетивизм или синонимия? // Смыслы, тексты и другие захватывающие сюжеты : сб. ст. в честь 80-летия И.А. Мельчука / отв. ред. Ю. Д. Апресян и др. М. : Языки славянских культур, 2012. С. 573-586.

Janda L.A., Endresen A., Kuznetsova J., Lyashevskaya O., Makarova A., Nesset T., Sokolova $S$. Why Russian Aspetucal Prefixes Aren't Empty (Prefixes as Verb Classifiers). Bloomington, Indiana : Slavica, 2013. 212 p.

Mel'čuk I. A. Suppletion: Toward a Logical Analysis of the Concept // Studies in Language. 1994. № 18 (2). P. 339-410.

Veselinova L.N. Suppletion in Verb Paradigms. Amsterdam, Philadelphia : Benjamins, 2006. $236 \mathrm{p}$.

\author{
Björn Wiemer \\ Johannes Gutenberg University Mainz \\ (Germany, Mainz) \\ wiemerb@uni-mainz.de
}

\title{
A DIFFERENT LOOK AT SYNONYMS AND SUPPLETION, THAT IS FROM THE PERSPECTIVE OF STEMS
}

The article deals with problems related to suppletion and demonstrates that, to some extent, these problems mirror phenomena which Ju.D. Apresjan qualified as redundant in the paradigms of verb stems entering into so-called aspect triplets. Both types 
of processes, those leading to suppletion and those conditioning an "overfill" of cells in assumed paradigms, require decisions concerning the relation between lexical units and grammar. Using this background, the article evaluates I. A. Mel'čuk's classification of suppletion and a couple of claims concerning the notions of lexeme and paradigm. Eventually, reasons are formulated which make us revise the conceptions of morphological paradigms and their relation to the notion of the lexeme. Such a conception should account for verb stems as units which form the basis of functional oppositions with a key role in Russian grammar. Concomitantly, it is suggested that a typology of suppletion should account not only for the degree of regularity in the formal relation between the units which are connected paradigmatically, but also for the productivity of morphological patterns. This applies to both the connections between units in the lexicon and their realization on the discourse level (type vs. token frequency).

Key words: the Russian language, paradigm, lexeme, suppletion, aspect triplets, systemic lexicography, verb stems, grammatical categories.

\section{References}

Apresyan Yu.D. [Morphological Information for an Explanative Dictionary]. Slovarnye kategorii [Categories of the Lexicon]. Yu.N. Karaulov (Ed.). Moscow, Nauka Publ., 1988, pp. 31-53. (In Russ.)

Apresyan Yu.D. Leksicheskaya semantika: sinonimicheskie sredstva yazyka [Lexical Semantics: Means of Synonymy in Language]. Moscow, Yazyki russkoi kul'tury Publ., 1995a, $481 \mathrm{p}$.

Apresyan Yu.D. [The Treatment of Redundant Aspectual Paradigms in the Explanatory Dictionary]. Apresyan Yu.D. Izbr. tr. T. 2: Integral'noe opisanie yazyka i sistemnaya leksikografiya [Selected Works. Vol. 2: The Integral Description of Language and Systemic Lexicography]. Moscow, Yazyki russkoi kul'tury Publ., 1995b, pp. 102-113. (In Russ.)

Apresyan Yu.D. [The Lexicographic Treatment of Aspect: Nontrivial Cases]. Trudy aspektologicheskogo seminara Filologicheskogo fakul'teta MGU im. M. V. Lomonosova. T. 2 [Studies of the Aspectological Seminar of the Faculty of Philology of the Moscow State University. Vol. 2]. M.Yu. Chertkova (Ed.). Moscow, Moscow St. Univ. Publ., 1997, pp. 7-20. (In Russ.)

Apresyan Yu.D. [The Interaction between Lexicon and Grammar: Lexicographic Aspect]. Russkii yazyk v nauchnom osveshchenii, 2002, No. 3 (1), pp. 10-29. (In Russ.)

Boguslavskaya O.Yu. [Close Synonyms: 250 years of Competition]. Smysly, teksty $i$ drugie zakhvatyvayushchie syuzhety: sb. st. $v$ chest' 80-letiya I. A. Mel'chuka [Senses, Texts and Other Exciting Topics : A Collection of Articles for Igor A. Melchuk on the Occasion of his $80^{\text {th }}$ Anniversary]. Yu.D. Apresyan et al. (Eds.) Moscow, Yazyki slavyanskikh kul'tur Publ., 2012, pp. 75-86. (In Russ.)

Dal' V.I. Tolkovyi slovar' zhivogo velikorusskogo yazyka [The Explanatory Dictionary of the Contemporary Great Russian Language] (Vols. 1-4). Moscow, St. Publ. of Foreign and National Dictionaries, 1956. 
Glovinskaya M.Ya. Semanticheskie tipy vidovykh protivopostavlenii russkogo glagola [The Semantic Types of Aspect Oppositions of the Russian Verb]. Moscow, Nauka Publ., 1982, 155 p. (In Russ.)

Gorbova E.V. [Aspect Formation of the Russian Verb: Prefixation and/or Suffixation?]. Voprosy yazykoznaniya, 2015, No. 1, pp. 7-38. (In Russ.)

Isachenko A.V. Grammaticheskii stroi russkogo yazyka v sopostavlenii s slovatskim. Morfologiya. Ch. 2 [The Grammatical Structure of Russian in Contrast with Slovak. Morphology. Iss. 2]. Moscow, Yazyki slavyanskikh kul'tur Publ., 2003, 570 p.

Janda L.A., Endresen A., Kuznetsova J., Lyashevskaya O., Makarova A., Nesset T., Sokolova S. Why Russian Aspetucal Prefixes Aren't Empty (Prefixes as Verb Classifiers). Bloomington, Indiana, Slavica Publ., 2013, 212 p.

Khrakovskii V.S. Aspektual'nye troiki i vidovye pary [Aspect Triplets and Pairs]. Russkii yazyk v nauchnom osveshchenii, 2005, No. 1, pp. 46-59. (In Russ.)

Mel'chuk I. A. [On Suppletion]. Problemy strukturnoi lingvistiki - 1971 [The Problems of Structural Linguistics - 1971]. S. K. Shaumyan (Ed.). Moscow, Nauka Publ., 1972, pp. 396-438. (In Russ.)

Mel'čuk I. A. Suppletion: Toward a Logical Analysis of the Concept. Studies in Language, 1994, No. 18 (2), pp. 339-410.

Mel'chuk I.A. Kurs obshchei morfologii. T. 4. Ch. 5: Morfologicheskie znaki [A Course on General Morphology. Vol. 4. Part 5: Morphological Signs]. Moscow, Vienna, Yazyki slavyanskikh kul'tur Publ., 2001, 580 p.

Natsional'nyi korpus russkogo yazyka [The National Corpus of the Russian Language]. Available at: http://ruscorpora.ru (accessed 15.07.2019, 22.11.2019)

Plungyan V.A. Obshchaya morfologiya (Vvedenie v problematiku) [General Morphology (An Introduction to Problems)]. Moscow, URSS Publ., 2000, 384 p.

Plungyan V.A. Vvedenie v grammaticheskuyu semantiku: grammaticheskie znacheniya i grammaticheskie sistemy yazykov mira [Introduction to Grammatical Semantics: Grammatical Meanings and Grammatical Systems in the Languages of the World]. Moscow, Russian St. Univ. for the Humanities Publ., 2011, 672 p.

Shmelev A.D. [Suppletion or Synonymy?]. Smysly, teksty i drugie zakhvatyvayushchie syuzhety: sb. st. $v$ chest' 80-letiya I. A. Mel'chuka [Senses, Texts and Other Exciting Topics : A Collection of Articles for Igor A. Melchuk on the Occasion of his $80^{\text {th }}$ Anniversary]. Yu.D. Apresyan et al. (Eds.). Moscow, Yazyki slavyanskikh kul'tur Publ., 2012, pp. 573-586. (In Russ.)

Veselinova L.N. Suppletion in Verb Paradigms. Amsterdam, Philadelphia, Benjamins Publ., 2006, 236 p.

Vinogradov V.V. Sovremennyi russkii yazyk. Morfologiya (Kurs lektsii) [Contemporary Russian Language. Morphology (A Series of Lectures)]. Moscow, Moscow St. Univ., 1952, 519 p. (In Russ.)

Wiemer B. [Aspectual Paradigms and the Lexical Meanings of Russian and Lithuanian Verbs (A Contrastive Study from the Point of View of Lexicalization and Grammaticalization)]. Voprosy yazykoznaniya, 2001, No. 2, pp. 26-58. (In Russ.) 
Wiemer B. [On the Role of Prefixes and Suffixes at the Early and Late Stages in the History of the Slavic Aspect]. The Role of Prefixes in the Formation of Aspectuality (Issues of Grammaticalization). R. Benacchio, A. Muro, S. Slavkova (Eds.). Firenze, Firenze Univ. Press, 2017, pp. 219-253. (In Russ.)

Wiemer B. [On the Semantically Invariant and Grammatically Trivial Components in the Russian Aspect]. Sbornik statei $k$ 85-letiyu V.S. Khrakovskogo [A Collection of Articles for the $85^{\text {th }}$ Anniversary of V.S. Khrakovsky]. D. S. Gerasimov, S.Yu. Dmitrenko, N. M. Zaika (Eds.). Moscow, Yazyki slavyanskikh kul'tu Publ., 2019, pp. 43-66. (In Russ.)

Zaliznyak A. A. Russkoe imennoe slovoizmenenie [Russian Nominal Inflection]. Moscow, Nauka Publ., 1967, 760 p.

Zaliznyak A. A., Mikaelyan I. L., Shmelev A.D. Russkaya aspektologiya: v zashchitu vidovoi pary [Russian Aspectology: in Defence of the Aspect Pair]. Moscow, Yazyki slavyanskikh kul'tur Publ., 2015, 392 p.

Zaliznyak A. A., Shmelev A.D. Vvedenie v russkuyu aspektologiyu [Introduction to Russian Aspectology]. Moscow, Yazyki slavyanskikh kul'tur Publ., 2000, 226 p. 


\title{
ЛЕКСИКОГРАФИЯ
}

https://doi.org/10.31912/pvrli-2020.3.11

\author{
Бьёрн Вимер \\ Университет Йоханнеса-Гутенберга \\ (Германия, Майни) \\ wiemerb@uni-mainz.de
}

\section{О СИНОНИМАХ И СУППЛЕТИВИЗМЕ НЕСКОЛЬКО ИНАЧЕ, ТО ЕСТЬ С ТОЧКИ ЗРЕНИЯ ОСНОВ}

В статье указывается, что проблемы, возникающие в связи с супплетивизмом, в известном смысле можно признать обратной стороной явлений, которые Ю. Д. Апресян рассматривал как проявления избыточности в парадигме глагольных основ, образующих так называемые видовые тройки. Как процессы, ведущие к супплетивизму, так и процессы, обусловливающие «переполнение» клеток в предполагаемых парадигмах, заставляют принимать решения о соотношении единиц словаря и грамматики. На этом фоне пересматривается классификация типов супплетивизма И. А. Мельчука и ряд положений, касающихся понятий лексемы и парадигмы. В результате обосновывается целесообразность ревизии представлений о морфологической парадигме и ее связи с понятием лексемы, которая учитывала бы глагольные основы как единицы, на которых строятся функциональные противопоставления, имеющие ключевую роль для грамматики русского языка. Вместе с тем выдвигается предложение учитывать в типологии супплетивизма не только степень регулярности формального соотношения объединяемых парадигматическими связями морфологических единиц, но и продуктивность морфологических образцов, причем как на уровне словарных единиц (включая варианты), так и на уровне текста (type vs. token frequency).

Ключевые слова: русский язык, парадигма, лексема, супплетивизм, видовые тройки, системная лексикография, глагольные основы, грамматические категории.

В настоящей статье я хочу показать, что хорошо известные идеи о роли структуры парадигм для системной лексикографии могут быть представлены в ином свете. Отправной точкой для этих рассуждений послужил ряд работ юбиляра, затрагивающих проблему «излишества» в парадигматических связях между единицами, морфологическим и лексикографическим отношениям которых обычно приписывался разный статус. Я стремлюсь к сопоставлению явлений, которые до сих пор в морфологических и лексикографических исследованиях скорее разъединялись 
(хотя бы частично), с тем, чтобы указать их сходство и чтобы высказаться за несколько измененный подход к «формату» единиц, соединяемых в парадигматических связях. Из соображений экономии места я ограничусь общей типологией затронутых здесь явлений и рядом частных вопросов.

\section{1. Исходные положения}

В «Лексической семантике» Ю. Д. Апресян [1995а: 173-175], рассматривая супплетивные отношения между разнокорневыми словами, обсуждал тройки слов типа:

(1а) бастовать - стачка / забастовка;

(1б) посещать - визит / посещение;

(1в) постановлять - резолюиия / постановление;

(1г) стоить - иена / стоимость.

В этих тройках выступают по два синонимичных (в определенной степени) существительных, из которых второе связано с глаголом словообразовательными аффиксами, а первое - нет. Поскольку в дополнительные отношения в качестве «именного репрезентанта» лексического концепта, выраженного глаголом, вступает уже второе, однокоренное существительное, то первое, разнокорневое существительное на право супплетивного отношения с глаголом претендовать не может. В этом смысле его в такой тройке можно считать лишним.

Такую «избыточность» Апресян сравнивал с ситуацией в несупплетивных тройках типа:

(2а) паковать - запаковать - запаковывать;

(2б) множить - умножить - умножать.

В отличие от троек в (1) все члены троек в (2) однокоренные и связаны словообразовательными аффиксами, все относятся к одной и той же части речи и у всех одно и то же лексическое значение. Однако в связи с принадлежностью к другому виду у среднего члена кардинально иное грамматическое распределение, чем у левого и правого членов, а эти два «крайних» члена между собой могут различаться всего лишь тонкими условиями употребления. В любом случае возникает вопрос, не нужно ли считать один из них лишним.

Тройки в (1) и в (2) роднит то, что между их членами наблюдается регулярное («нормальное») семантическое соотношение в рамках некоего лексического концепта; в этом смысле их члены могут считаться синонимами, но один из них может показаться излишним: в (1) это два члена, разделенные косой чертой, а в (2) это два крайних члена по отношению к среднему. Однако степень формального различия разная; разными также являются причины близкого семантического родства ${ }^{8}$.

${ }^{8}$ В отличие от троек типа (2) между членами троек типа (1) наблюдается не только различное этимологическое происхождение, но и намного больше разнообразия в семантических 
Поскольку и в формальном, и в семантическом плане члены троек типа (2) заметно ближе друг к другу, чем члены троек типа (1), то с их лексикографической трактовкой возникает больше проблем. Видимо, именно поэтому Ю. Д. Апресян [1995а: 174, сноска 4] подчеркивал, что иллюстрировать проблемы, связанные с супплетивизмом, удобнее как раз на примере троек типа (2). В более поздней работе [Апресян 1988], в основном воспроизведенной в [Апресян 1995б], юбиляр на примере этих троек разбирал вопрос синонимии и вариантов. Тройки типа (2) известны как видовые тройки, точнее как биимперфективные видовые тройки: «...на роль имперфективного коррелята претендует сразу два глагола» [Зализняк и др. 2015: 58 и след.]. По отношению к ним часто обсуждался вопрос, за каким из этих двух глаголов нужно признавать право быть «собственно видовым» коррелятом.

\section{2. Супплетивизм, синонимия и распределение по грамматическим функциям}

Прежде чем обратиться к этому вопросу, хотелось бы осветить теоретический фон, на котором Апресян провел нестандартную аналогию между тройками типа (1) и видовыми тройками. Исходной точкой для этой аналогии послужили положения Мельчука о супплетивизме 9 . Они эксплицитно учитывают продуктивные образцы в словообразовании и даже за его пределами [см.: Мельчук 2001: 420441]. Так, например, в [Mel'čuk 1994: 363; Мельчук 2001: 438 и след.] супплетивизм усматривается даже между полной фраземой и семантически соответствующим именем деятеля:

$$
\begin{aligned}
& \text { говорить красиво - краснобай; } \\
& \text { молоть языком - пустозвон. }
\end{aligned}
$$

Эти пары слов в целом могут быть охарактеризованы как антонимы друг к другу, а в формальном плане соотношения между членами каждой из пар одинаковые, хотя морфологически почти ничего общего между ними нет ${ }^{10}$. Столь далеко идущее применение понятия супплетивизма показывает, что различия между словоизменением и словообразованием (как бы они ни определялись) не имеют значения. Мельчуку в первую очередь важно охватить л юбы е образцы семантического соотношения между единицами языка, которые в какой-то заметной степени отклоняются от регулярных способов его формального выражения [cм.: Mel'čuk 1994:

отношениях. Апресян здесь приводит такие примеры, как действовать - эффект / действие, создавать - автор / создатель, а также примеры с другими частями речи, например единственный - только / единственно, совпадать - тождественный / совпадающий.

9 Хотя точной ссылки в данном месте книги не дается, понятно, что Апресян опирался на работу [Мельчук 1972]. Ее положения отразились и в более известной статье [Mel'čuk 1994].

10 Видимо, мысль о супплетивизме возникает именно из-за антонимии, позволяющей построить аналогичную схему:

$\begin{array}{ll}\text { говорить красиво } & : \text { молоть языком } \\ \text { краснобай } & : \text { пустозвон }\end{array}$


344; Veselinova 2006: 164]. При этом степень продуктивности выделяемых образцов, видимо, роли не играет ${ }^{11}$.

Что касается различия между словоизменительным и словообразовательным супплетивизмом, то считается, что в первом случае супплетивные знаки относятся к одной и той же лексеме (и поэтому здесь говорится о «формах»), а в случае второго - к разным лексемам, связанным отношениями производности [Мельчук 2001: 429].

Кроме этих особенностей, нужно отметить следующие положения Мельчука.

1. Понятие «супплетивизм» применяется к парам минимальных знаков, а таковыми считаются как морфы и мегаморфы (т.е. морфологически неразложимые сегменты, обслуживающие более одного грамматического и/или лексического значения) ${ }^{12}$, так и фразеологизованные словосочетания [Мельчук 2001: 421, 423], примеры которых можно увидеть в (3).

2. Супплетивизм - градуальное свойство, которое зависит от степени формальной нерегулярности [Мельчук 2001: 426-428, 439]. Самая сильная степень супплетивизма достигается, когда какие-либо два соотнесенных парадигматически знака $\mathrm{S}_{1}$ и $\mathrm{S}_{2}$ нельзя свести ни друг к другу, ни к какому-либо третьему знаку с помощью активных морфонологических чередований (например, реб-ён-ок-дет- $u$, но также четыре - сорок). Со слабым супплетивизмом мы имеем дело, когда обнаруживается какое-либо уникальное чередование, но «формальное сходство между $\mathrm{S}_{1}$ и $\mathrm{S}_{2}$ не слишком велико, чтобы признать их безоговорочно супплетивными» [Там же: 440]; ср. англ. child — child-ren, лит. žmog-us 'человек' — žmon-ёs 'люди', а также при-еха-ть - при-езжса-ть.

3. Как супплетивные могут определяться отношения не только среди лексических морф, т. е. аллолексов (например, франц. all-ons - i-r-ons '(мы) идем - пой-

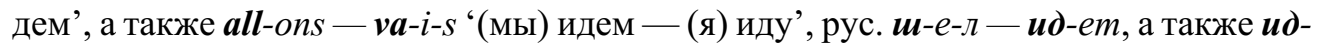
em (или $\boldsymbol{и д - m u ) ~ - ~} \boldsymbol{x} \boldsymbol{\partial}-\varnothing$, но и среди морф с грамматическими значениями (включая и словообразовательные), например (много) стол-ов, деревь-ев, словар-ей, книг-ө. Тем самым алломорфизм в области аффиксов трактуется как частный случай супплетивизма [Мельчук 2001: 422, 429, 433].

4. Мегаморфы могут выражаться в виде целых словоформ, представляющих сплав лексического значения с функциями граммем, т.е. корни неотделимы от грамматических показателей, а точнее говоря, корни сами выступают показателями грамматических значений в рамках определенных парадигм (ср. англ. am are - is - was - were - be).

5. Между тем исключается супплетивизм между лексическими синонимами, если между ними нет никаких грамматических различий (например, огромн-ыци громадн-biй). Хотя это явно не сказано, но причина очевидным образом состоит

11 Как раз с этой точки зрения примеры (3) очень сомнительны. В общем и целом проблемы с продуктивностью редко когда подвергались критической оценке в работах по супплетивизму: «The issue of productivity and generality of a derivational pattern is rarely discussed at length in relation to suppletion» [Veselinova 2006: 13]. Систематический обзор см. [Там же: 9-18, 163-169].

12 Более принятый термин - морфемы-портманто. 
а единая парадигма мыслима только по отношению к лексеме; понятия эти создают замкнутый круг. Если же следовать определению классифицирующей категории, данному в [Плунгян 2011: 53], то единства парадигмы по отношению к парным основам СВ и НСВ нет: «определенное множество лексем данного языка без остатка разбивается на непересекающиеся подклассы, каждый из которых характеризуется своим значением некоторой грамматической категории. Эта категория приписана, таким образом, лексемам, а не словоформам и задает грамматическую классификацию лексики» (курсив в оригинале).

В частном случае парные основы могут быть супплетивными, и то как исключения на фоне регулярных образцов, в соответствии с которыми глагольные основы связаны между собой деривационными аффиксами. А откуда тогда берутся значения граммем СВ : НСВ, которые приписываются этим основам? Очевидно, они выводятся только из глобального распределения морфологически соотносительных основ по разным группам функций. Грубо говоря, основы класса СВ выступают только в одних группах контекстов, основы класса НСВ встречаются, соответственно, в других, а контексты (функции) обоих классов в идеале распределены дополнительно. Отсюда и грамматический характер оппозиции СВ : НCB, и непересекающиеся подклассы (см. выше цитату из Плунгяна). Чтобы завершить круг рассуждений, нужно осознать, что разнокорневые, но синонимичные основы объединяются в видовые пары потому, что между ними наблюдается в принципе то же распределение, что и между членами видовых пар, образованных по регулярным аффиксальным образцам. Нужным может оказаться еще дополнительное условие, что такие разнокорневые основы не имеют регулярных соответствий противоположного вида. Почему без этого условия лексикографическая трактовка материала усложняется, станет понятным в $\$ 3.4$.

Далее, нужно понимать, что видовые пары - это всего лишь случаи полной лексической синонимии между основами с разным распределением по выше упомянутым контекстам, т.е. между представителями противопоставленных грамматических классов. Разное распределение между понимаемыми так синонимами включает устойчивые условия замены одного члена пары другим. Наиболее распространенные условия замены получили название частновидовые функиии. К ним относятся и те, в которых глагол НСВ мыслится как «заместитель» СВ в событийном значении (нарративное настоящее, многократное, а отчасти и общефактическое); эти условия получили название тривиальныле ${ }^{15}$. Разумеется, все эти условия и распределение по контекстам применяются по отношению к лексемам, представителями которых выступают основы. Но большая (если не преобладающая) часть споров о том, какие основы СВ и НСВ считать видовыми парами, вытекала из разных представлений о лексической синонимии и о тождестве лексических концептов. При этом нужно осознавать, что даже в бесспорных видовых парах толкования члена СВ и члена НСВ часто расходятся. Это показано, например, в работе [Гловинская 1982].

15 Более систематическое представление дается в [Зализняк, Шмелев 2000; Вимер 2001; 2017]. 


\section{3. Избыточность... чего? - вариантов, синонимов или функций?}

В дальнейшем я хочу обсудить, что в русской видовой системе делает супплетивные синонимы возможными. Заодно хочется указать на ряд проблем, которые возникают вследствие жесткой взаимной «увязки» понятий парадигмы и лексемы.

\section{1. Вариативные суффиксы}

Для обсуждения этих вопросов полезно вернуться к лексикографической трактовке видовых троек, изложенной в двух статьях нашего юбиляра [Апресян 1988; 1995б]. В них обсуждались не только биимперфективные тройки, но также тройки, в которых две основы НCB отличаются суффиксами $\{$ 'a $\} /\{\text { va }\}^{16}$ и $\{$ iva $\}$; например:

\begin{tabular}{lll} 
СВ & \multicolumn{1}{|l}{ НСВ } & НСВ \\
завернуть - заворачивать & завертьвать (покупку в бумагу) \\
заготовить - заготавливать / заготовлять (дрова на зиму) \\
осмыслить - осмыслять $/$ осмысливать (увиденное) \\
рассеять - рассеивать $/$ рассевать (пепел по ветру) \\
наре́зать - нареза́ть
\end{tabular}

Эти суффиксы вряд ли имеют статус отдельных морфем и даже статус алломорфов, поскольку сложно понять, на чем основывается их распределение. Сосуществующие основы НСВ практически не отличаются друг от друга значением, так что их следует считать вариантами, а вопрос о разных лексемах не встает. Именно этим данный тип троек кардинально отличается от биимперфективных троек (см. § 3.2). В тройках типа (5) основным вариантом НСВ обычно считается первый (перед косой чертой), а второй ущербен в том смысле, что он употребляется реже и часто ощущается как архаичный. Поскольку не удается установить общие правила распределения вариантов, каждый случай нуждается в индивидуальном словарном описании. В этом смысле он неудобен как для лексикографического описания, так и для установления связей с грамматическими правилами.

Как варианты Апресян оценивает также сосуществующие основы на -стичь и -стигнуть. Стоит отметить, что эти основы связанные, т. е. они не встречаются без приставок ${ }^{17}$. На самом деле такие варианты создают тройки, прямо противоположные тройкам в (5), поскольку две вариантные основы СВ противостоят одной основе НСB, например:

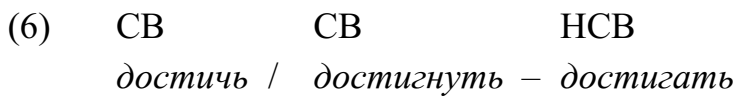

16 Для данного рассуждения не имеет значения, нужно ли считать $\{$ 'a $\}$ и $\{\mathrm{va}\}$ разными алломорфами или нет.

${ }^{17} \mathrm{Cp}$. с -нять (по-нять, при-нять, за-нять и т. д.) и рядом других случаев. О связанных корнях и основах см. [Плунгян 2000: 50-51]. 
Однако вариантные основы СВ обнаруживают тенденцию к дополнительному распределению финитных и нефинитных форм: от основ -стичь преимущественно образуются формы прошедшего времени, тогда как от основ - стигнуть - формы будущего времени и все нефинитные формы ${ }^{18}$ [Апресян 1988: 37], т. е. вариативные основы начинают «делить между собой» совокупность флективных форм, включая и те, которые входят в расширенную парадигму нефинитных форм.

По мере того как распределение приближается к дополнительному, о простой вариативности говорить не приходится. Поэтому в плане взаимодействия с грамматическими правилами тройки типа (6) нуждаются в более пристальном внимании, чем тройки типа (5), у которых тенденции к дополнительному распределению флективных финитных и нефинитных форм не наблюдается (по крайней мере, мне неизвестно, чтобы кто-либо такую тенденцию отмечал). Тем не менее тройки в (5) и (6) роднит то, что вариативность основ не влечет за собой семантических последствий, в частности нет сколько-нибудь заметной тенденции к дополнительному распределению по видовым функциям.

То же самое в принципе можно сказать и о другом типе, который Апресян обсуждал в связи с вариативностью суффиксов. Речь идет о случаях, когда основа без дополнительного суффикса ведет себя как двувидовая, но имеется и дериват с суффиксом \{iva $\}$, который принимает на себя функции $\mathrm{HCB}$; ср., например, apecтовать - арестовывать. Апресян трактует двувидовую основу как представителя двух ф о р м глагола: одной для СВ и одной для НСВ. О проблемах со словоизменительной трактовкой видовой оппозиции СВ : НСВ уже говорилось выше. Альтернативно на данные случаи можно смотреть и так: имеются основы, которые на фоне всей классифицирующей системы не ведут себя однозначно ни как НСВ, ни как СВ, но есть и дериваты, которые нужно расценить как основы НСВ, хотя они и недостаточно «надежны» (т.е. предсказуемы - в зависимости от контекстов, требующих или предпочитающих либо СВ, либо НСВ), и поэтому основа без этого суффикса может по-прежнему выполнять функции, «предусмотренные» для $\mathrm{HCB}^{19}$. Такая ненадежность и приводит к тому, что информация о возможности использования несуффигированной основы как НСВ заносится в индивидуальную словарную статью. В плане распределения видовых функций между такими основами получается асимметрия.

\section{2. Биимперфективные тройки}

В обсуждении биимперфективных троек полезно различать две вещи: принципиальные рассуждения относительно их лексикографической трактовки, с одной стороны, и критерии их подразделения, с другой. Мы начнем с первого вопроса;

18 В соответствии с [Veselinova 2006] такое распределение характерно для некатегориального супплетивизма (non-categorial suppletion).

19 Вместе с тем, как указывал Апресян, многие основы без суффикса \{iva\} ущербны в плане частновидовых функций, а их суффиксальные дериваты склонны использоваться в дополнительных частновидовых функциях [Апресян 1988: 36]. По сути это обратная сторона того же явления. 
для него окажется существенным понимание парадигмы и ее соотношения с понятием лексемы, т.е. той единицы, которая по сути является основным объектом лексикографического описания. В тройках бесприставочную основу НСВ я в дальнейшем буду называть $\mathrm{HCB}_{1}$, а основу вторичного имперфектива (с другим суффиксом) - $\mathrm{HCB}_{2}$. Ср., например:

$$
\begin{aligned}
& \mathrm{HCB}_{1} \mathrm{CB} \\
& \text { множить }- \text { умножить }- \text { умножать } \\
& \text { мести }- \text { подмести }- \text { подметать }
\end{aligned}
$$

Ю. Д. Апресян [1988; 1995б] рассматривает три альтернативные трактовки; первые две из них на деле реализованы в русской лексикографической практике. В соответствии с первой трактовкой в пару объединяются СВ и $\mathrm{HCB}_{2}$ :

$\begin{array}{ccc}\mathrm{HCB}_{1} & \mathrm{CB} \quad \mathrm{HCB}_{2} \\ \text { IPFV tantum }^{20} & \text { пара }\end{array}$

$\mathrm{C}$ ней проблема в основном такова, что семантически $\mathrm{HCB}_{1}$ отстоит от $\mathrm{CB}$ не больше, чем $\mathrm{HCB}_{2}$ от СВ. Предположение о том, что нет, например, * ${ }^{2}$ дельввать, * написывать (и что поэтому $\mathrm{HCB}_{1}$ делать и писать объединяются с СВ сделать и написать в пары), а существует $\mathrm{HCB}_{2}$ умножать и т.д., само по себе не дает основания усматривать разницу лексического значения между $\mathrm{HCB}_{1}$ и $\mathrm{HCB}_{2}$ [Апресян 1988: 39 и след.]. Вместе с тем представленное выше решение нельзя распространить на все тройки; ср., например, есть - съесть - съедать: тут скорее $\mathrm{HCB}_{2}$ отстоит от двух остальных основ (см. ниже).

Второй подход состоит в выделении двух равноправных пар таким образом, что СВ оказывается «шарниром», выступая членом СВ сразу в двух разных парах:

$$
\begin{array}{lll}
\mathrm{HCB}_{1} \mathrm{CB} & \mathrm{HCB}_{2} \\
\hline
\end{array}
$$

При таком решении проблема заключается в том, что «умножить объявляется формой СВ от двух разных слов, т. е элементов двух разных парадигм. Такое пересечение парадигм лингвистическая теория считает невозможным. <..> Получается парадокс: множить и умножать суть разные лексемы (синонимы), входящие в грамматическую парадигму одной и той же лексемы умножить» [Апресян 1988: 38]. Существенно, что данный парадокс возникает, оттого что между лексемой и парадигмой устанавливается одно-однозначная связь; поэтому нельзя «перекрестить» две парадигмы или, что при словоизменительном подходе равнозначно, две лексемы.

Желая избежать такого парадокса, мы могли бы обсудить еще и третье решение. Оно сводилось бы к тому, чтобы объединить все три члена тройки в единую парадигму:

$$
\begin{array}{lll}
\mathrm{HCB}_{1} & \mathrm{CB} & \mathrm{HCB}_{2} \\
\hline
\end{array}
$$

20 То есть основа НСВ без соотносительной основы СВ. 
Тогда $\mathrm{HCB}_{1}$ и $\mathrm{HCB}_{2}$ объявлялись бы вариантами друг друга, т. е., по сути дела, за ними признавался бы такой же статус, как за основами с вариативными суффиксами (типа засеивать / засевать; см. 5), хотя формальное различие между $\mathrm{HCB}_{1}$ и $\mathrm{HCB}_{2}$ больше, чем между такими суффиксальными вариантами.

Такую трактовку Апресян принципиально отвергает: «признание множить умножить - умножать формами одного слова и, следовательно, элементами одной парадигмы логически приводит к такой ревизии глагольных парадигм, которая ни в какую реалистическую картину языка не укладывается» [Апресян 1988: 39]. Такой подход нужно считать «противоестественным», поскольку мы признавали бы, что «язык позволяет себе роскошь иметь от двух до пяти одинаково жизнеспособных вариантов одной и той же грамматической формы, порождаемых к тому же вполне живыми, а иногда и продуктивными процессами видо- и словообразования» [Там же: 40]. Дело бы не кончилось одними тройками, а распространялось бы дальше - на четвертки, пятерки и т. д., например:

$$
\begin{aligned}
& \text { менять (иголки на шкуры - обменять -обменивать - поменять; } \\
& \text { платить (за проезд) - уплатить - уплачивать - заплатить; } \\
& \text { рвать (отночения) - разорвать - разрывать - порвать; }
\end{aligned}
$$

готовить (инструмент) - приготовить - приготавливать - приготовлять;

мерить (туфли) - примерить - примерять - примеривать;

кутать (ребенка в платок) - закутать - закутьльть - укутать - укутьватын;

лечить (ребенка от кори) - вылечить - вылечивать - излечить - излечивать;

молотить (рожь) - обмолотить - обмолачивать - смолотить - смолачивать;

копить (деньги) - накопить - накапливать - накоплять - скопить скапливать - (разг.) скоплять

В связи с этими принципиальными возражениями Апресян пишет, что разная номенклатура (словоизменение, словообразование, классификационная категория, видообразование) вряд ли поможет понять «сущность русского вида». С тем, что терминология, если она сводится лишь к замене ярлыков, сама по себе ничего не решает, нельзя не согласиться. Однако интересно, что Апресян сам часто говорит о «видообразовании», очевидно потому, что этот термин более «безопасен», чем традиционное деление на словоизменение и словообразование: этот термин не заставляет определять морфологический статус обсуждаемых операций и единиц по отношению к грамматике и словарю ${ }^{21}$. Все равно мы оказались в тупике: ни одна из рассмотренных трактовок

${ }^{21}$ Не желая вступать здесь в эту дискуссию, я хотел бы лишь указать на довольно длительную историю этого понятия, применяемого как своего рода «стратегия избежания». Эта история начинается по меньшей мере с работы [Исаченко 2003 (1960): 137] и продолжается поныне; ср. недавнюю статью [Горбова 2015]. 
не оказалась безупречной. Тем важнее предложение Апресяна, как выбраться из этого тупика: не следует впадать в иллюзию, будто возможно дать всем биимперфективным тройкам одинаковую трактовку; сходство их формального устройства необязательно говорит о том, что они тождественны также и содержательно.

Тем самым мы переходим к подразделению биимперфективных троек. Апресян [1988; 1995б] выделял четыре подтипа, причем представляют они собой лишь наиболее яркие участки некоторого континуума. Полужирным шрифтом обозначаются члены, которые, по Апресяну, имеют наибольшие права на парность:

$\mathbf{H C B}_{1}-\mathbf{C B}-\mathrm{HCB}_{2}$ например: вить (гнездо) - свить - свивать

$\mathrm{HCB}_{1}-\mathbf{C B}-\mathbf{H C B}_{2}$ например: жать (штангу) - выжать - выжимать

$\left(\mathrm{HCB}_{1}\right)-\mathbf{C B}-\mathbf{H C B}_{2}$ например: гореть - сгореть - сгорать

$\mathbf{H C B}_{1}-\mathbf{C B}-\left(\mathrm{HCB}_{2}\right)$ например: nuть - выпить - выпивать

Интерес вызывает прежде всего второй подтип. В нем право на видовую парность признается за СB и $\mathrm{HCB}_{2}$, а $\mathrm{HCB}_{1}$ считается IPFV tantum, синонимичным с парой $\mathrm{CB}-\mathrm{HCB}_{2}$. Однако $\mathrm{HCB}_{1}$ употребляется взамен форм этой пары в речи, если у говорящего «возникает в этом необходимость, например: Tbl что сейчас делаешь? - Пакую вещи. - Когда запакуешь, зайди» [Апресян 1995а: 175; 1988: 42; 1995б: 111]. См. также:

$$
\text { — Что ты делаешь? - Мету пол. — Когда подметешь, вымой посуду. }
$$

В таких случаях говорится о «несобственных формах» и указывается на параллель со словообразовательным супплетивизмом из (1): - Сколько стоит эта книга? - Пять. - За такую цену ее никто не купит, хотя тут о (несобственных) формах той же лексемы нет речи.

В этом механизме Апресян усматривает компенсацию «дефектной парадигмы одной лексемы за счет форм другой, синонимичной ей лексемы» [Апресян 1988: 42], и здесь он вводит разграничение между системой (фиксируемой в словаре) и узусом (наблюдаемым в речи). Тут напрашивается вопрос, почему вообще парадигма видовой пары считается дефектной; иначе говоря, почему в примерах типа (12) не употребляется $\mathrm{HCB}_{2}$ подметаю? Если подметать и мести синонимичны, но только подметать определяется в качестве «парного» НСВ к СВ подмести, то естественно ожидать, что подметать может выбираться во всех основных видовых функциях, свойственных основам НСВ, в том же лексическом значении, что и $\mathrm{CB}$, или что подметать имеет хотя бы больше видовых функций, чем мести, в разных типах контекстов, в которых СВ заменяется на равнозначный $\mathrm{HCB}$. А если $\mathrm{HCB}_{1}$ и $\mathrm{HCB}_{2}$ возможны в равной мере, то весь вопрос сводится к тому, какой из них чаще на деле реализуется в каком-то достаточно четко определенном типе контекстов (т. е. в том или ином частновидовом значении). А то, что окажется более частотной реализацией, будет соответствовать системе или узусу?

Подобное явление, как и подобный вопрос, возникает применительно к $\mathrm{HCB}_{1}$ из третьего подтипа, ср.: 
- Спасибо скажи, что не пишу протокол, не привлекаю. - Не дам... Я лучше сожгу его! - Жги ... - спокойно ответил участковый и поднял глаза, огляделся. - Жги. Как раз ветерок к твоей хате. Ветер и вправду с утра шумел, серебря маковки тополей, легко пригибая их (Б. Екимов. Пиночет. 1999) [НКРЯ].

В третьем подтипе $\mathrm{HCB}_{1}$ считается более отдаленным от $\mathrm{CB}-\mathrm{HCB}_{2}$, потому что приставочные основы не могут употребляться в контекстах, в которых предел подавляется (или он нерелевантен); ср.: В комнате горит / *сгорает лампа или Костер горит $\neq$ сгорает быстро. Напротив, в четвертом подтипе $\mathrm{HCB}_{2}$ считается более отдаленным от $\mathrm{HCB}_{1}-\mathrm{CB}$, поскольку $\mathrm{HCB}_{2}$ употребителен в многократных контекстах, но неприменим или избегается в процессной функции (ср. Смотри, он nьет / *выпивает) $)^{22}$. Здесь стоит обратить внимание, что обоснования для определения «собственно видовой пары» из двух НСВ в каждом из двух случаев разные: в четвертом подтипе обоснование опирается на ограниченный набор частновидовых функций у $\mathrm{HCB}_{2}$, тогда как в третьем подтипе обоснованию подлежат различия в семантическом потенциале и вместе с тем разные синтаксически реализуемые валентности.

На самом деле одни и те же исследователи, подразделяя типы биимперфективных троек, исходят из разных критериев. Их можно вкратце охарактеризовать следующим образом.

1. Какой НСВ заменяет СВ в тривиальных условиях? Здесь на первом плане стоит возможность онтологического тождества обозначаемой ситуации.

2. Имеют ли $\mathrm{HCB}_{1}$ и $\mathrm{HCB}_{2}$ тенденцию к дополнительному распределению по частновидовым функциям (включая тривиальные), т.е. различаются ли оба $\mathrm{HCB}$ в семантическом (акциональном) плане, но каждый из них может лексически заменить СВ? Если да, то следует ли это расценить как свидетельство того, что оба HCB образуют с СB совместную парадигму (как в формальном, так и в функциональном отношении)? Апресян от такой возможности категорически отказался, назвав ее «противоестественной» (см. выше).

3. Какой из НСВ обладает более широким набором частновидовых (в том числе тривиальных) функций и выступает в них чаще, чем другой НСВ? И какие из этих значений следует признать основными? В принципе такой вопрос был задан в [Апресян 1997], но трудно сказать, какие значения следует признать (более) основными.

4. У какого из НСВ больше совместных с СВ лексических значений (включая их варианты) с учетом синтаксически реализуемых валентностей? Этот вопрос четче всех ориентирован на лексикографическое описание. См. соответствующий анализ в [Храковский 2005: 53-57], а также анализ «биперфективной» тройки в [Богуславская 2012] (см. § 3.3).

Эти критерии практически нигде эксплицитно не различаются, хотя во многих случаях они приводят к разным результатам, прежде всего в оценке троек [см.: Вимер 2019: 49-56].

22 Точнее говоря, процессная функция возможна, но только если дополнительно вводятся количественные ограничители действия; ср.: Смотри, он выпивает одну кружку за другой. 
Как бы то ни было, способность $\mathrm{HCB}_{1}$ заменять $\mathrm{CB}$, особенно в тройках подтипов 3 и 4, Ю. Д. Апресян [1995б] охарактеризовал как функцию «джокера»: $\mathrm{HCB}_{1}$ способен обозначать тот же лексический концепт, что и СВ (и парный с ним $\mathrm{HCB}_{2}$ ), только менее точно; уточнение же вносит речевой контекст. И тут снова возникает вопрос о том, что в каком-то определенном типе контекстов реализуется чаще. Конечно, на этот вопрос можно ответить только после корпусного исследования, в котором тщательно контролируются контекстные условия. Но даже если такое весьма трудоемкое - исследование будет проведено и окажется, что в тройках, относящихся к любому из указанных выше подтипов (по Апресяну), $\mathrm{HCB}_{1}$ заменяет $\mathrm{CB}$ чаще, чем $\mathrm{HCB}_{2}$, то какой вывод можно будет из такого результата извлечь для словарного описания? Нельзя отрицать существование $\mathrm{HCB}_{2}$, но $\mathrm{HCB}_{1}$ может оказаться более предсказуемым в качестве «лексической копии» СВ в тех контекстах, в которых СВ употребляться не может (или избегается).

Оппозиция между системой и узусом становится шаткой (или вообще распадается), если то, что считают «потенциалом системы», лишь изредка реализуется в речи (или не реализуется вообще). Апресян сам, хотя и косвенно, приходит к подобному выводу в двух моментах. Первый момент просматривается в критериях выделения четвертого подтипа биимперфективных троек, в которых $\mathrm{HCB}_{2}$ признается искусственным. Такие $\mathrm{HCB}_{2}$ «могут быть получены по продуктивным моделям видообразования, но скорее в виде потенциальных, чем реально используемых форм» [Апресян 1988: 41]. Второй момент был уже отмечен выше в связи с первой из возможных лексикографических трактовок биимперфективных троек: нельзя сказать, что объединение $\mathrm{HCB}_{2}$ (например, умножать) и $\mathrm{CB}$ (умножить и т. д.) в видовую пару само по себе может быть достаточным основанием для того, чтобы признать соотносительный $\mathrm{HCB}_{1}$ (множить и т. д.) IPFV tantum, и наоборот - что самим отсутствием $\mathrm{HCB}_{2}$ (например, сдельввать, написывать) можно обосновать решение, чтобы признать бесприставочную основу НСВ и соотносительную основу СВ видовой парой (делать - сделать, писать - написать и т.д.). В обоих лексикографических рассуждениях за исходное берется реализуемое, а не потенциальное. Вместе с тем вряд ли случайно, что искусственное отождествляется с редким, т. е. частотность хотя бы на интуитивном уровне влияет на предварительную сортировку материала по лексикографическим типам.

Вернемся еще ко второму из упомянутых только что рассуждений: ошибкой было бы считать бесприставочную основу глаголом IPFV tantum по одной лишь причине, что имеется $\mathrm{HCB}_{2}$ от соотносительной основы $\mathrm{CB}^{23}$. Для лексикографии проблемы создает особенно то обстоятельство, что вторичные имперфективы стали самым продуктивным способом образования основ НСВ из основ СВ. Существует много окказиональных и прочих образований, не принятых современной лексикографией, но иногда проживающих «подпольно» очень долгое время. Например,

${ }^{23}$ Обратной стороной той же медали является мнение разных ученых, что $\mathrm{HCB}_{2}$ следует считать излишним, если имеется однокоренной $\mathrm{HCB}_{1}$ (= бесприставочная основа). См., например, мнение П. С. Кузнецова в [Виноградов 1952: 320]. 
написывать в [НКРЯ] (старая версия, запрос делался в середине июля 2019 г.) имеет всего лишь девять вхождений в восьми документах, а последнее вхождение приходится на 1920 г.:

(14) Я в беспрерывном творчестве. Но вовсе не ведаю, что мне делать с написывающцмися стихами (К. Д. Бальмонт. Письма М. А. Волошину. 1920).

Между тем запрос в «Гугл» (середина июля 2019 г.) позволил убедиться, что основа $\mathrm{HCB}_{2}$ написывать (во всех основных употреблениях $\mathrm{HCB}_{1}$ писать) попрежнему «жива». Нетрудно найти примеры типа:

(15) Почему девушки часто начинают написывать бывшим парням в соцсети после того, как случайно их встретят на улице?? [https:/otvet.mail.ru/ question/215265044].

Ввиду таких фактов постоянно возникает проблема учета «избыточности» с точки зрения лексикографии. На их примере можно убедиться в том, что язык (так сказать, через речь) постоянно позволяет себе роскошь излишества, причем несущественно, какой морфологический (и грамматический) статус мы будем признавать за наблюдаемой избыточностью (словоизменение, словообразование или, во избежание лишних дискуссий, видообразование). Намного интереснее понять, какие факторы приводят к тому, что одни варианты пробивают себе путь, другие вытесняются, а третьи могут сосуществовать довольно долго. И интересно, примет ли системная лексикография вызов, чтобы отражать эту динамику в своем моделировании.

«Редундантные отношения», стоящие за появлением вторичных имперфективов и за устройством той части видовой системы, которая связана с тройками (в частности, с биимперфективными), часты. Они могут появиться и снова исчезнуть в отдельных случаях, но как общее, динамическое явление они, видимо, будут сохраняться, пока вторичная имперфективация не перестанет быть продуктивной, а бесприставочные основы не исчезнут, - а ни на то, ни на другое не похоже.

Замечательно, что подобная динамика учитывалась в двух случаях супплетивизма, из которых один прямым образом связан с видом (§ 3.3), а другой показывает рост тенденции к дополнительному распределению этимологически различных, но синонимичных основ (§ 3.5). К этому можно добавить случаи наложения супплетивизма на видовые тройки, расположенные будто бы посередине (§ 3.4). Все эти явления хорошо вписываются в типологию соотношений супплетивизма и синонимии. Поэтому ими хочется завершить настоящий обзор.

\section{3. Особый случай: биперфективная видовая тройка}

В работе [Богуславская 2012] был проведен анализ корпусных данных, показывающих, как на протяжении примерно 250 лет в морфологически регулярной паре НСВ - СВ член СВ заменялся на другой, этимологически (почти) не соотносительный: в паре возвращзать - возвратить на смену возвратить все больше 
приходил вернуть; аналогичная ситуация имела место и относительно возвратного возвращаться - возвратиться / вернуться ${ }^{24}$. Замена не дошла до конца, поэтому и сегодня вернуть (ся) и возвратить (ся) сосуществуют рядом практически во всех своих значениях и на этом основании имеют почти одинаковое право на видовую парность с НСВ возвращать (ся).

Правда, вернуть (ся) сегодня намного частотнее, чем возвратить(ся). С одной стороны, более старый член СВ (возвратить(ся)) лучше укоренен в языковой системе в том смысле, что у него более развиты словообразовательные связи (ср. возврат, невозвратный и т.д.); от этой основы также образуется причастие в пассиве, тогда как вернуть не образует нужных для пассива форм причастий, т. е. его парадигма слегка дефектна. Заодно перед нами дополнительное распределение, подобное распределению у связанных основ типа -стичь/-стигнуть (см. § 3.1). С другой стороны, у вернуть и вернуться чуть более развита полисемия (с вариантами значений), чем у возвратить и возвратиться [см.: Богуславская 2012: 77-82]. В то же время необходимо учесть также приставочные дериваты обеих основ СВ. Для возвратить таких дериватов нет (может быть, потому, что в эту основу уже входит приставка), зато у вернуть их множество, ср. неполный список: ввернуть, вывернуть, повернуть, свернуть, завернуть, провернуть, развернуть, отвернуть, перевернуть, подвернуть (аналогично для вернуться vs. возвратиться).

Устройство тройки возвращаться - возвратиться / вернуться представляет собой зеркальное отражение устройства биимперфективных троек, и поэтому ее можно назвать биперфективной. Но на этом, пожалуй, сопоставимость кончается. Во-первых, биперфективная тройка строится на супплетивной замене (см. сноску 17); бывшая видовая пара возвращзаться - возвратиться в формальном отношении подверглась расподоблению. Во-вторых, насколько мне известно, такой случай для русского языка единичен, в то время как биимперфективных троек весьма много. Эта уникальность объясняется, видимо, тем, что верну- - одна из немногих бесприставочных основ (из славянского фонда морфем), которые относятся к $\mathrm{CB}$, а также тем, что вернуть(ся) с точки зрения морфемной структуры не обладает (с середины XVIII в. ${ }^{25}$ ) эквивалентом НСВ. Поэтому до того, как эти основы «вторглись» на место возвратить (ся), их можно было отнести к perfectiva tantum. Есть, правда, случаи (тоже единичные), в которых основа СВ с одной приставкой

24 Корни верт(еть) / вер(нуть) и ворот(ить) этимологически родственны в очень далеком прошлом [подробнее см.: Богуславская 2012: 76], но вряд ли распознаваемы как однокоренные в современном языке, а врат (umb) — церковнославянское соответствие полногласного ворот(umb). Оба тем самым изначально являются вариантами, но (как обычно в литературном русском языке при «дублетах» славянизма и его восточнославянского эквивалента) сейчас находятся в практически дополнительном лексическом распределении. К тому же -вратить превратилось в связанную основу.

25 Судя по данным [НКРЯ] и по словарю В.И. Даля [1: 182], вертеть и вертеться по крайней мере с середины XVIII в. выступали только в тех значениях, которые известны в современном языке. Однокоренные основы верте $(m b)$ и верну $(m b)$ должны были семантически разъединиться достаточно давно. 
«подшивается» под однокоренную пару с другой приставкой; ср. уснуть по отношению к заснуть - засыпnámb. Но в таком случае, как правило, о тройке не говорится. Видимо, это не столько потому, что уснуть стилистически маркировано и вместе с тем встречается несколько реже, чем заснуть (7 809 против 11206 вхождений в [НКРЯ] - новая версия, запрос от 22 ноября 2019 г.), сколько потому, что мену приставок не считают проявлением алломорфизма, даже если получаемые основы синонимичны (в отличие от мены суффиксов; см. § 3.1). Следовательно, однокоренные основы с разными приставками трактуются как разные лексемы.

\section{4. Обязательно ли супплетивизм противодействует лексическому единству в тройке?}

На этом фоне интересно отметить, что возникновение супплетивной пары $\mathrm{HCB}$ - СВ может помешать образованию биимперфективной тройки. См. соотношения основ в (16):

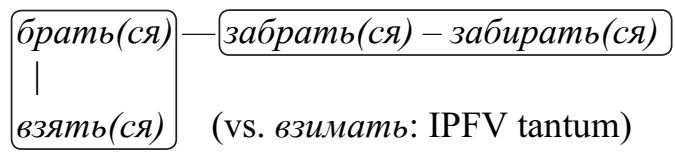

Когда-то основа СВ взять(ся) семантически отъединилась от «родственной» основы НСВ взимать(ся). Взимать обособилось как imperfectivum tantum, но взять (ся) вступило в дополнительное грамматическое распределение со своим синонимом брать(ся), так что обе основы стали одной из самых частотных, если не самой частотной видовой парой. Теперь на момент отвлечемся и прикинем, что случилось бы, если бы основы НСВ брать(ся) не «нашли себе» дополнительных партнеров СВ взять(ся). Тогда было бы трудно отказаться от мысли, что брать(ся) имеет смысл рассматривать как $\mathrm{HCB}_{1}$ к забрать (ся) - забирать (ся), а все три основы вместе - как биимперфективные тройки. По сути дела, и сегодняшний супплетивизм брать (ся) - взять(ся) в принципе не мешает рассматривать такую нестандартную трактовку: в (16) была бы представлена биимперфективная тройка с одним разнокорневым синонимом, дублирующим функции члена СВ. Насколько я могу судить, лексикографическая практика такую альтернативную трактовку не учитывает. И если это так, то такая практика имплицитно признает супплетивизм по виду более адекватным «отражением реальности», чем возможность объединения бесприставочных основ НСВ в тройки (или соединения супплетивизма с тройкой).

Что, однако, делать в случае, когда от бесприставочной основы НСВ образуется сразу два деривата СВ с разными приставками и каждый из этих дериватов, в свою очередь, образует вторичный имперфектив? При этом все пять основ имеют одинаковое лексическое значение. См., например:

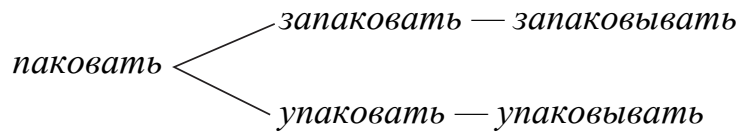


Такие случаи не обособленны, так что ими пренебречь нельзя (см. подробный разбор в [Janda et al. 2013: §§ 5-6]). Перед нами как будто две вставленные друг в друга биимперфективные тройки четвертого подтипа (см. § 3.2), а вдобавок оба приставочных СВ имеют равное право считаться «собственно видовым» коррелятом НСВ паковать. В [Апресян 1995а: 174-175] эта ситуация представляется как своего рода дилемма (с точки зрения словоизменения), поскольку не только паковать соотносится одновременно с двумя синонимичными дериватами $\mathrm{CB}$, но и все дериваты СВ и НСВ с приставками за- и $y$ - синонимичны друг другу и поэтому могут в пределах «своих» частновидовых значений заменять друг друга.

Думается, что дилемма снимается, если допустить полностью синонимичные отношения между однокорневыми видовыми парами с разными приставками, которые в дополнение ведут себя как «спаренные» через $\mathrm{HCB}_{1}$ биимперфективные тройки. Если $\mathrm{HCB}_{1}$ паковать все равно признается «джокером» (см. § 3.2), то оно с лексикографической точки зрения и так стоит особняком, а «группировки родственных основ», как в (17), предстают как крайние случаи, когда вследствие деривации основ в пределах одной части речи лексическое значение остается неизменным. В конце концов, тройкам как таковым в праве существования не отказывают (см. $\S 3.2$ ), а существуют также синонимичные видовые пары, образованные от разных корней, у которых распределение видовых функций (в большей или меньшей мере) совпадает, но никто не думает объединять их в одну парадигму; ср., например, близкозначные пары зарывать - зарыть и закапывать - закопать, спешить - поспешить и торопиться - поторопиться, притворяться - притвориться и прикидываться - прикинуться, отнимать - отнять и отбирать — отобрать.

Здесь можно вернуться к началу статьи и указать на аналогию между «пятеркой» в (17) и словообразовательной пятеркой с меной части речи и супплетивными членами, как в (18):

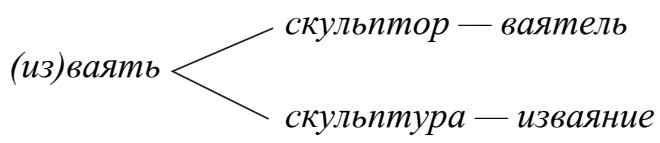

Исходный глагол становится «шарниром» для двух пар синонимов, в каждой из которых один член делит корень с исходным глаголом. Соотношение между ваять и скульптор / ваятель (или между изваять и скульптура / изваяние) вряд ли можно считать тройкой, но собственно только потому, что ни между синонимичными существительными (в каждой паре), ни между глаголом и любой из пар существительных нет грамматических условий распределения (кроме «тривиальных» условий, требующих той или иной части речи).

\section{5. Слияние неполных парадигм синонимов в единую супплетивную парадигму}

В работе [Апресян 2002: § 2.1] описывается процесс взаимного дополнения парадигмы финитных и нефинитных форм двух близкозначных глаголов - хотеть и желать: хотеть стилистически нейтрально употребляется в финитных формах 
утвердительных и вопросительных предложений, а желать - в нефинитных формах и в императиве, к тому же этот глагол обладает более развитыми словообразовательными связями (ср. желание, пожелание, желательный). Апресян подводит следующий итог: «Распределение личных и неличных форм глаголов хотеть и желать еще не приобрело той стройности, которая характеризует дополнительное распределение. В частности, у обоих есть нейтральный инфинитив» [Там же: 19]. Тем не менее: «Налицо тенденция к слиянию двух неполных парадигм близко синонимичных глаголов в одну супплетивную парадигму. <..> В результате желать и хотеть тяготеют к слиянию в один глагол с супплетивной грамматической и словообразовательной парадигмами, в которых все члены стилистически нейтральны» [Там же: 19].

Как этот пример, так и пример с вернуть(ся) в 3.3 уместно считать случаями превращения «несобственных форм», заполняющих лакуны в парадигме другой основы, в супплетивные эквиваленты ${ }^{26}$. Впрочем, даже среди членов достаточно бесспорных видовых пар синонимия может оказаться неполной. Так, например, А. Д. Шмелев [2012: 584] показал, что НСВ ударять не может заменять «свой» СВ ударить в сочетании ударить по воротам. В этом (и видимо, только в этом) сочетании место ударять занимает бить (по воротам). Такой идиосинкратический случай иллюстрирует зачаток развития фразем, включающих супплетивизм. Заодно такие зачатки создают лексикографические проблемы различения вариантов и синонимов.

Конечно, для каждого отдельного случая встает вопрос, действительно ли лакуны возникли до того, как их стали заполнять формы другой основы (pull-in effect), или же регулярные формы парадигмы вытеснялись вроде бы «излишними» формами синонимичной основы (push-out effect). Но сравнение таких случаев показывает, что подобные процессы приводят к изменениям в видовой парности так же, как и в более традиционных парадигматических отношениях (обсуждаемых в рамках словоизменения).

\section{4. Заключение}

Явления, в которых можно усмотреть супплетивизм, крайне интересны для оценки «серой зоны» между словарем и грамматикой [Veselinova 2006], и тем самым для фундаментальных задач системной лексикографии. Супплетивные отношения нельзя считать просто случайными причудами языка. Напротив, они свидетельствуют о том, что парадигматические структуры подвержены изменениям, и в большой мере из-за того, что между членами этих структур часто наблюдается асимметрия, а семантически или функционально близкие средства, у которых по разным причинам меняется продуктивность, способны занимать «слабые звенья» (или клетки) в парадигмах. Это верно независимо от того, какой

26 Этот механизм хорошо описан в [Veselinova 2006], причем как для категориального, так и для некатегориального супплетивизма. 
морфологический статус признается за задействованными единицами; как справедливо сказано в [Veselinova 2006: 10]: «...it is not always entirely clear where one is to draw the line between suppletive forms related in a derivational way on the one hand, and separate lexical items on the other. In this respect, suppletion draws the limit of the possible word». Как я попытался показать, в известном смысле обратной стороной супплетивизма являются рассмотренные Апресяном типы избыточности форм в парадигме. Процессы, ведущие к супплетивизму, равно как процессы, обусловливающие «переполнение» клеток в предполагаемых парадигмах, заставляют принимать решения о соотношении единиц словаря (а такая единица принимается как общее для всех форм парадигмы значение) и грамматики (в которой определяются правила соединения словарных единиц с членами парадигмы).

Заодно решения, которые принимаются в серых зонах, много говорят о модели, заложенной самими лингвистами. С особой остротой проблемы вырисовываются, когда мы углубляемся в исследование типов образования глагольных основ в русском языке. Поскольку вид относится к стержневым грамматическим категориям в любом славянском языке, а в дополнение он теснейшим образом связан с глагольной лексикой (не только в славянских языках), эти проблемы оказывались устойчивыми с момента возникновения аспектологических разысканий также и для русского языка и, естественно, для концепции интегрального словаря. Сомнительно, что эти проблемы удастся преодолеть, если вокруг видообразования ведутся споры о том, нужно ли рассматривать русский вид как словоизменительную категорию или как другой тип категории, а не спрашивается просто о том, какой ти п е дин иц создает парадигматические отношения - и на основании каких семанти ческих (или функциональных) противопоставлений. Вместе с тем необходимо определиться, сколь жестко понимается лексическое тождество и как поступать с зачатками идиосинкратического ограничения лексической сочетаемости (ср. пример бить / *ударять - ударить по воротам, приведенный в § 3.5), а также как расценивать различия в частотности вариантов или синонимов (см. § 3.13.2). В связи с супплетивизмом Мельчук задавал шкалу регулярности (по форме), но очевидным образом мы нуждаемся также в шкале по продуктивности применения морфологических образцов, причем отдельно для продуктивности в отношении словарных единиц (включая варианты) и в отношении реализации на уровне текста (type vs. token frequency). Уместно расширить учет супплетивизма на уровень соотношения основ, связанных словообразовательными отношениями в пределах одной части речи. Мельчук предпринял этот шаг фактически именно на примере супплетивных видовых пар, хотя тем самым он показал неправомерность одной из своих предпосылок (см. § 2). Супплетивные видовые пары строятся на синонимии глагольных основ с дополнительным распределением по грамматически релевантным контекстам. Вдобавок хотя бы одна из этих основ должна была «лишиться» своего коррелята оппозитивного вида; если же у другой основы осталась связь с синонимичной и словообразовательно «родственной» основой противоположного вида (или со стандартной видовой парой), возможные супплетивные и регулярные отношения накладываются друг на друга (ср. пример 16). 
Предложенное расширение типологии супплетивизма позволяет увидеть градуальность и сходство в соотношениях между корнями, основами и аффиксами, т.е. между единицами разного морфологического «формата» (и способами их соединения). В связи с этим стоило бы подумать над ревизией представлений о морфологической парадигме и ее связи с понятием лексемы. В частности, почему нельзя признать единую парадигму за родственными, но разными лексемами, например в видовых тройках?

\section{Литература}

Апресян Ю.Д. Морфологическая информация для толкового словаря // Словарные категории / отв. ред. Ю. Н. Караулов. М. : Наука, 1988. С. 31-53.

Апресян Ю.Д. Лексическая семантика: синонимические средства языка. М. : Языки русской культуры, 1995а. 481 с.

Апресян Ю. Д. Трактовка избыточных аспектуальных парадигм в толковом словаре // Апресян Ю. Д. Избр. тр. Т. 2 : Интегральное описание языка и системная лексикография. М. : Языки русской культуры, 1995б. С. 102-113.

Апресян Ю. Д. Лексикографическая трактовка вида: нетривиальные случаи // Труды аспектологического семинара Филологического факультета МГУ им. М. В. Ломоносова. Т. 2 / отв. ред. М. Ю. Черткова. М. : Изд-во МГУ, 1997. С. 7-20.

Апресян Ю. Д. Взаимодействие лексики и грамматики: лексикографический аспект // Русский язык в научном освещении. 2002. №3 (1). С. 10-29.

Богуславская О. Ю. Близкие синонимы: 250 лет соперничества // Смыслы, тексты и другие захватывающие сюжеты : сб. ст. в честь 80-летия И. А. Мельчука / отв. ред. Ю. Д. Апресян и др. М. : Языки славянских культур, 2012. С. 75-86.

Вимер Б. Аспектуальные парадигмы и лексическое значение русских и литовских глаголов (Опыт сопоставления с точки зрения лексикализации и грамматикализации) // Вопросы языкознания. 2001. № 2. С. 26-58.

Вимер Б. О роли приставок и суффиксов на ранних и поздних этапах истории славянского вида // The Role of Prefixes in the Formation of Aspectuality (Issues of Grammaticalization) / ed. by R. Benacchio, A. Muro, S. Slavkova. Firenze : Firenze University Press, 2017. P. 219-253.

Вимер Б. О семантически инвариантном и грамматически тривиальном в русском виде // Сборник статей к 85-летию В. С. Храковского / отв. ред. Д. С. Герасимов, С. Ю. Дмитренко, Н. М. Заика. М. : Языки славянских культур, 2019. С. 43-66.

Виноградов В. В. Современный русский язык. Морфология (Курс лекций). М. : Изд-во МГУ, 1952. 519 с.

Гловинская М.Я. Семантические типы видовых противопоставлений русского глагола. М. : Наука, 1982. 155 с.

Горбова Е. В. Видообразование русского глагола: префиксация и/или суффиксация? // Вопросы языкознания. 2015. №1. С. 7-38.

Даль В. И. Толковый словарь живого великорусского языка : в 4 т. М. : Гос. издво иностр. и нац. словарей, 1956. 
Зализняк А. А. Русское именное словоизменение. М. : Наука, 1967. 760 с.

Зализняк А. А., Микаэлян И.Л., Шмелев А. Д. Русская аспектология: в защиту видовой пары. М. : Языки славянских культур, 2015. 392 с.

Зализняк А. А., Шмелев А. Д. Введение в русскую аспектологию. М. : Языки славянских культур, 2000. 226 с.

Исаченко A.В. Грамматический строй русского языка в сопоставлении с словацким. Морфология. Ч. 2. М. : Языки славянских культур, 2003. 570 с.

Мельчук И. А. О супплетивизме // Проблемы структурной лингвистики - 1971 / отв. ред. С. К. Шаумян. М. : Наука, 1972. С. 396-438.

Мельчук И. А. Курс общей морфологии. Т. 4. Ч. 5 : Морфологические знаки. М. ; Вена : Языки славянских культур, 2001. 580 с.

НКРЯ - Национальный корпус русского языка [Электронный ресурс]. URL: http://ruscorpora.ru/

Плунгян B.A. Общая морфология (Введение в проблематику). M. : URSS, 2000. $384 \mathrm{c}$.

Плунгян В.A. Введение в грамматическую семантику: грамматические значения и грамматические системы языков мира. М. : Изд-во РГГУ, 2011. 672 с.

Храковский В. С. Аспектуальные тройки и видовые пары // Русский язык в научном освещении. 2005. № 1. С. 46-59.

Шмелев А. Д. Супплетивизм или синонимия? // Смыслы, тексты и другие захватывающие сюжеты : сб. ст. в честь 80-летия И.А. Мельчука / отв. ред. Ю. Д. Апресян и др. М. : Языки славянских культур, 2012. С. 573-586.

Janda L.A., Endresen A., Kuznetsova J., Lyashevskaya O., Makarova A., Nesset T., Sokolova $S$. Why Russian Aspetucal Prefixes Aren't Empty (Prefixes as Verb Classifiers). Bloomington, Indiana : Slavica, 2013. 212 p.

Mel'čuk I. A. Suppletion: Toward a Logical Analysis of the Concept // Studies in Language. 1994. № 18 (2). P. 339-410.

Veselinova L.N. Suppletion in Verb Paradigms. Amsterdam, Philadelphia : Benjamins, 2006. $236 \mathrm{p}$.

\author{
Björn Wiemer \\ Johannes Gutenberg University Mainz \\ (Germany, Mainz) \\ wiemerb@uni-mainz.de
}

\title{
A DIFFERENT LOOK AT SYNONYMS AND SUPPLETION, THAT IS FROM THE PERSPECTIVE OF STEMS
}

The article deals with problems related to suppletion and demonstrates that, to some extent, these problems mirror phenomena which Ju.D. Apresjan qualified as redundant in the paradigms of verb stems entering into so-called aspect triplets. Both types 
of processes, those leading to suppletion and those conditioning an "overfill" of cells in assumed paradigms, require decisions concerning the relation between lexical units and grammar. Using this background, the article evaluates I. A. Mel'čuk's classification of suppletion and a couple of claims concerning the notions of lexeme and paradigm. Eventually, reasons are formulated which make us revise the conceptions of morphological paradigms and their relation to the notion of the lexeme. Such a conception should account for verb stems as units which form the basis of functional oppositions with a key role in Russian grammar. Concomitantly, it is suggested that a typology of suppletion should account not only for the degree of regularity in the formal relation between the units which are connected paradigmatically, but also for the productivity of morphological patterns. This applies to both the connections between units in the lexicon and their realization on the discourse level (type vs. token frequency).

Key words: the Russian language, paradigm, lexeme, suppletion, aspect triplets, systemic lexicography, verb stems, grammatical categories.

\section{References}

Apresyan Yu.D. [Morphological Information for an Explanative Dictionary]. Slovarnye kategorii [Categories of the Lexicon]. Yu.N. Karaulov (Ed.). Moscow, Nauka Publ., 1988, pp. 31-53. (In Russ.)

Apresyan Yu.D. Leksicheskaya semantika: sinonimicheskie sredstva yazyka [Lexical Semantics: Means of Synonymy in Language]. Moscow, Yazyki russkoi kul'tury Publ., 1995a, $481 \mathrm{p}$.

Apresyan Yu.D. [The Treatment of Redundant Aspectual Paradigms in the Explanatory Dictionary]. Apresyan Yu.D. Izbr. tr. T. 2: Integral'noe opisanie yazyka i sistemnaya leksikografiya [Selected Works. Vol. 2: The Integral Description of Language and Systemic Lexicography]. Moscow, Yazyki russkoi kul'tury Publ., 1995b, pp. 102-113. (In Russ.)

Apresyan Yu.D. [The Lexicographic Treatment of Aspect: Nontrivial Cases]. Trudy aspektologicheskogo seminara Filologicheskogo fakul'teta MGU im. M. V. Lomonosova. T. 2 [Studies of the Aspectological Seminar of the Faculty of Philology of the Moscow State University. Vol. 2]. M.Yu. Chertkova (Ed.). Moscow, Moscow St. Univ. Publ., 1997, pp. 7-20. (In Russ.)

Apresyan Yu.D. [The Interaction between Lexicon and Grammar: Lexicographic Aspect]. Russkii yazyk v nauchnom osveshchenii, 2002, No. 3 (1), pp. 10-29. (In Russ.)

Boguslavskaya O.Yu. [Close Synonyms: 250 years of Competition]. Smysly, teksty $i$ drugie zakhvatyvayushchie syuzhety: sb. st. $v$ chest' 80-letiya I. A. Mel'chuka [Senses, Texts and Other Exciting Topics : A Collection of Articles for Igor A. Melchuk on the Occasion of his $80^{\text {th }}$ Anniversary]. Yu.D. Apresyan et al. (Eds.) Moscow, Yazyki slavyanskikh kul'tur Publ., 2012, pp. 75-86. (In Russ.)

Dal' V.I. Tolkovyi slovar' zhivogo velikorusskogo yazyka [The Explanatory Dictionary of the Contemporary Great Russian Language] (Vols. 1-4). Moscow, St. Publ. of Foreign and National Dictionaries, 1956. 
Glovinskaya M.Ya. Semanticheskie tipy vidovykh protivopostavlenii russkogo glagola [The Semantic Types of Aspect Oppositions of the Russian Verb]. Moscow, Nauka Publ., 1982, 155 p. (In Russ.)

Gorbova E.V. [Aspect Formation of the Russian Verb: Prefixation and/or Suffixation?]. Voprosy yazykoznaniya, 2015, No. 1, pp. 7-38. (In Russ.)

Isachenko A.V. Grammaticheskii stroi russkogo yazyka v sopostavlenii s slovatskim. Morfologiya. Ch. 2 [The Grammatical Structure of Russian in Contrast with Slovak. Morphology. Iss. 2]. Moscow, Yazyki slavyanskikh kul'tur Publ., 2003, 570 p.

Janda L.A., Endresen A., Kuznetsova J., Lyashevskaya O., Makarova A., Nesset T., Sokolova S. Why Russian Aspetucal Prefixes Aren't Empty (Prefixes as Verb Classifiers). Bloomington, Indiana, Slavica Publ., 2013, 212 p.

Khrakovskii V.S. Aspektual'nye troiki i vidovye pary [Aspect Triplets and Pairs]. Russkii yazyk v nauchnom osveshchenii, 2005, No. 1, pp. 46-59. (In Russ.)

Mel'chuk I. A. [On Suppletion]. Problemy strukturnoi lingvistiki - 1971 [The Problems of Structural Linguistics - 1971]. S. K. Shaumyan (Ed.). Moscow, Nauka Publ., 1972, pp. 396-438. (In Russ.)

Mel'čuk I. A. Suppletion: Toward a Logical Analysis of the Concept. Studies in Language, 1994, No. 18 (2), pp. 339-410.

Mel'chuk I.A. Kurs obshchei morfologii. T. 4. Ch. 5: Morfologicheskie znaki [A Course on General Morphology. Vol. 4. Part 5: Morphological Signs]. Moscow, Vienna, Yazyki slavyanskikh kul'tur Publ., 2001, 580 p.

Natsional'nyi korpus russkogo yazyka [The National Corpus of the Russian Language]. Available at: http://ruscorpora.ru (accessed 15.07.2019, 22.11.2019)

Plungyan V.A. Obshchaya morfologiya (Vvedenie v problematiku) [General Morphology (An Introduction to Problems)]. Moscow, URSS Publ., 2000, 384 p.

Plungyan V.A. Vvedenie v grammaticheskuyu semantiku: grammaticheskie znacheniya i grammaticheskie sistemy yazykov mira [Introduction to Grammatical Semantics: Grammatical Meanings and Grammatical Systems in the Languages of the World]. Moscow, Russian St. Univ. for the Humanities Publ., 2011, 672 p.

Shmelev A.D. [Suppletion or Synonymy?]. Smysly, teksty i drugie zakhvatyvayushchie syuzhety: sb. st. $v$ chest' 80-letiya I. A. Mel'chuka [Senses, Texts and Other Exciting Topics : A Collection of Articles for Igor A. Melchuk on the Occasion of his $80^{\text {th }}$ Anniversary]. Yu.D. Apresyan et al. (Eds.). Moscow, Yazyki slavyanskikh kul'tur Publ., 2012, pp. 573-586. (In Russ.)

Veselinova L.N. Suppletion in Verb Paradigms. Amsterdam, Philadelphia, Benjamins Publ., 2006, 236 p.

Vinogradov V.V. Sovremennyi russkii yazyk. Morfologiya (Kurs lektsii) [Contemporary Russian Language. Morphology (A Series of Lectures)]. Moscow, Moscow St. Univ., 1952, 519 p. (In Russ.)

Wiemer B. [Aspectual Paradigms and the Lexical Meanings of Russian and Lithuanian Verbs (A Contrastive Study from the Point of View of Lexicalization and Grammaticalization)]. Voprosy yazykoznaniya, 2001, No. 2, pp. 26-58. (In Russ.) 
Wiemer B. [On the Role of Prefixes and Suffixes at the Early and Late Stages in the History of the Slavic Aspect]. The Role of Prefixes in the Formation of Aspectuality (Issues of Grammaticalization). R. Benacchio, A. Muro, S. Slavkova (Eds.). Firenze, Firenze Univ. Press, 2017, pp. 219-253. (In Russ.)

Wiemer B. [On the Semantically Invariant and Grammatically Trivial Components in the Russian Aspect]. Sbornik statei $k$ 85-letiyu V.S. Khrakovskogo [A Collection of Articles for the $85^{\text {th }}$ Anniversary of V.S. Khrakovsky]. D. S. Gerasimov, S.Yu. Dmitrenko, N. M. Zaika (Eds.). Moscow, Yazyki slavyanskikh kul'tu Publ., 2019, pp. 43-66. (In Russ.)

Zaliznyak A. A. Russkoe imennoe slovoizmenenie [Russian Nominal Inflection]. Moscow, Nauka Publ., 1967, 760 p.

Zaliznyak A. A., Mikaelyan I. L., Shmelev A.D. Russkaya aspektologiya: v zashchitu vidovoi pary [Russian Aspectology: in Defence of the Aspect Pair]. Moscow, Yazyki slavyanskikh kul'tur Publ., 2015, 392 p.

Zaliznyak A. A., Shmelev A.D. Vvedenie v russkuyu aspektologiyu [Introduction to Russian Aspectology]. Moscow, Yazyki slavyanskikh kul'tur Publ., 2000, 226 p. 